Cochrane Database of Systematic Reviews

\title{
Stem cell transplantation for ischemic stroke (Review)
}

Boncoraglio GB, Ranieri M, Bersano A, Parati EA, Del Giovane C

Boncoraglio GB, Ranieri M, Bersano A, Parati EA, Del Giovane C.

Stem cell transplantation for ischemic stroke.

Cochrane Database of Systematic Reviews 2019, Issue 5. Art. No.: CD007231.

DOI: 10.1002/14651858.CD007231.pub3.

www.cochranelibrary.com 
TABLE OF CONTENTS

ABSTRACT 1

PLAIN LANGUAGE SUMMARY

SUMMARY OF FINDINGS

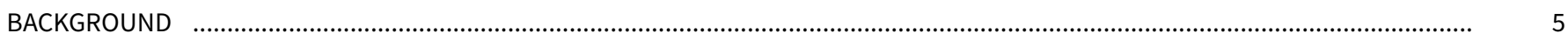

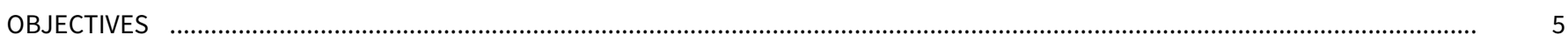

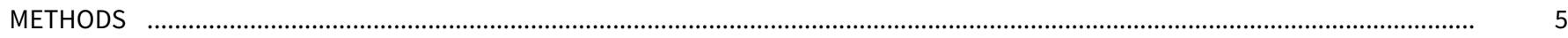

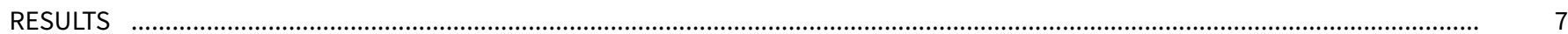

Figure 1. . .

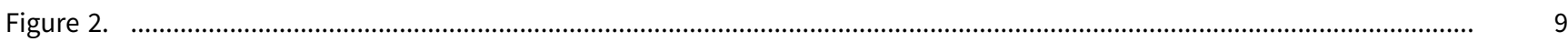

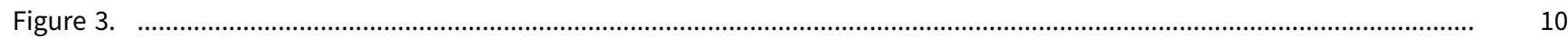

DISCUSSION

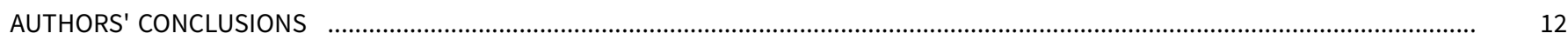

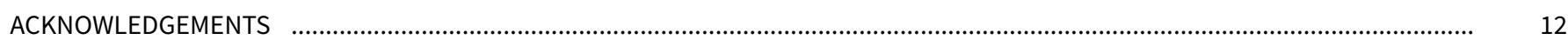

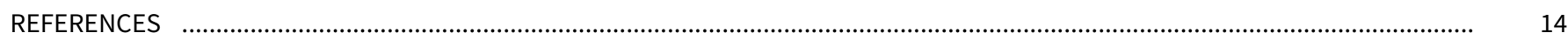

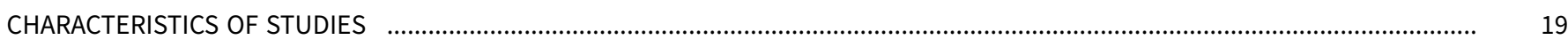

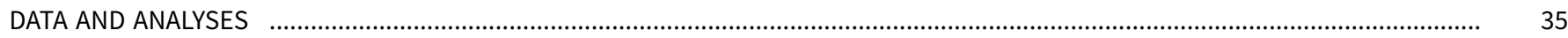

Analysis 1.1. Comparison 1 Stem cell transplantation versus conventional treatments, Outcome 1 Neurologic impairment 36 (measured by NIHSS).

Analysis 1.2. Comparison 1 Stem cell transplantation versus conventional treatments, Outcome 2 Neurologic impairment (measured by NIHSS, by phase of disease).

Analysis 1.3. Comparison 1 Stem cell transplantation versus conventional treatments, Outcome 3 Neurologic impairment (measured by NIHSS, by route of administration).

Analysis 1.4. Comparison 1 Stem cell transplantation versus conventional treatments, Outcome 4 Disability (measured by $\mathrm{mRS})$.

Analysis 1.5. Comparison 1 Stem cell transplantation versus conventional treatments, Outcome 5 Disability (measured by mRS, by phase of disease).

Analysis 1.6. Comparison 1 Stem cell transplantation versus conventional treatments, Outcome 6 Disability (measured by mRS, by route of administration).

Analysis 1.7. Comparison 1 Stem cell transplantation versus conventional treatments, Outcome 7 Dependency (measured by BI).

Analysis 1.8. Comparison 1 Stem cell transplantation versus conventional treatments, Outcome 8 Dependency (measured by $\mathrm{BI}$, by route of administration).

Analysis 1.9. Comparison 1 Stem cell transplantation versus conventional treatments, Outcome 9 Any cause of death. .......... Analysis 1.10. Comparison 1 Stem cell transplantation versus conventional treatments, Outcome 10 Severe worsening of neurological deficit.

Analysis 1.11. Comparison 1 Stem cell transplantation versus conventional treatments, Outcome 11 Infections.

Analysis 1.12. Comparison 1 Stem cell transplantation versus conventional treatments, Outcome 12 Neoplastic transformation of ischemic lesion at longer-term follow-up.

APPENDICES

WHAT'S NEW

CONTRIBUTIONS OF AUTHORS

DECLARATIONS OF INTEREST

DIFFERENCES BETWEEN PROTOCOL AND REVIEW

INDEX TERMS 
[Intervention Review]

\section{Stem cell transplantation for ischemic stroke}

Giorgio Battista Boncoraglio1,2, Michela Ranieri ${ }^{1}$, Anna Bersano ${ }^{1}$, Eugenio A Parati ${ }^{1}$, Cinzia Del Giovane ${ }^{3}$

1Department of Neurology, Fondazione IRCCS Istituto Neurologico "Carlo Besta", Milano, Italy. 2PhD Program in Neuroscience, Università di Milano - Bicocca, Monza, Italy. ${ }^{3}$ Institute of Primary Health Care (BIHAM), University of Bern, Bern, Switzerland

Contact: Giorgio Battista Boncoraglio, Department of Neurology, Fondazione IRCCS Istituto Neurologico "Carlo Besta", Via Celoria 11, Milano, 20133, Italy. giorgio.boncoraglio@istituto-besta.it.

Editorial group: Cochrane Stroke Group.

Publication status and date: New search for studies and content updated (no change to conclusions), published in Issue 5, 2019.

Citation: Boncoraglio GB, Ranieri M, Bersano A, Parati EA, Del Giovane C. Stem cell transplantation for ischemic stroke. Cochrane Database of Systematic Reviews 2019, Issue 5. Art. No.: CD007231. DOI: 10.1002/14651858.CD007231.pub3.

Copyright (c) 2019 The Cochrane Collaboration. Published by John Wiley \& Sons, Ltd.

\section{A B S T R A C T}

\section{Background}

Stroke is a leading cause of morbidity and mortality worldwide, with very large healthcare and social costs, and a strong demand for alternative therapeutic approaches. Preclinical studies have shown that stem cells transplanted into the brain can lead to functional improvement. However, to date, evidence for the benefits of stem cell transplantation in people with ischemic stroke is lacking. This is the first update of the Cochrane review published in 2010.

\section{Objectives}

To assess the efficacy and safety of stem cell transplantation compared with control in people with ischemic stroke.

\section{Search methods}

We searched the Cochrane Stroke Group Trials Register (last searched August 2018), CENTRAL (last searched August 2018), MEDLINE (1966 to August 2018), Embase (1980 to August 2018), and BIOSIS (1926 to August 2018). We handsearched potentially relevant conference proceedings, screened reference lists, and searched ongoing trials and research registers (last searched August 2018). We also contacted individuals active in the field and stem cell manufacturers (last contacted August 2018).

\section{Selection criteria}

We included randomized controlled trials (RCTs) that recruited people with ischemic stroke, in any phase of the disease (acute, subacute or chronic), and an ischemic lesion confirmed by computerized tomography or magnetic resonance imaging scan. We included all types of stem cell transplantation, regardless of cell source (autograft, allograft, or xenograft; embryonic, fetal, or adult; from brain or other tissues), route of cell administration (systemic or local), and dosage. The primary outcome was efficacy (assessed as neurologic impairment or functional outcome) at longer term follow-up (minimum six months). Secondary outcomes included post-procedure safety outcomes (death, worsening of neurological deficit, infections, and neoplastic transformation).

\section{Data collection and analysis}

Two review authors independently applied the inclusion criteria, assessed trial quality and risk of bias, and extracted data. If needed, we contacted study authors for additional information. We performed random effects meta-analyses when two or more RCTs were available for any outcome. We assessed the certainty of the evidence by using the GRADE approach.

\section{Main results}

In this updated review, we included seven completed RCTs with 401 participants. All tested adult human non-neural stem cells; cells were transplanted during the acute, subacute, or chronic phase of ischemic stroke; administered intravenously, intra-arterially, intracerebrally, or into the lumbar subarachnoid space. Follow-up ranged from six months to seven years. Efficacy outcomes were measured with the 
National Institutes of Health Stroke Scale (NIHSS), modified Rankin Scale (mRS), or Barthel Index (BI). Safety outcomes included case fatality, and were measured at the end of the trial.

Overall, stem cell transplantation was associated with a better clinical outcome when measured with the NIHSS (mean difference [MD] $-1.49,95 \%$ confidence interval $[\mathrm{Cl}]-2.65$ to -0.33 ; five studies, 319 participants; low-certainty evidence), but not with the mRS (MD -0.42 , $95 \% \mathrm{Cl}-0.86$ to 0.02 ; six studies, 371 participants; very low-certainty evidence), or the $\mathrm{BI}$ (MD $14.09,95 \% \mathrm{Cl}-1.94$ to 30.13 ; three studies, 170 participants; very low-certainty evidence). The studies in favor of stem cell transplantation had, on average, a higher risk of bias, and a sample size of 32 or fewer participants.

No significant safety concerns associated with stem cell transplantation were raised with respect to death (risk ratio [RR] $0.66,95 \% \mathrm{Cl} 0.39$ to 1.14; six studies, participants; low-certainty evidence).

We were not able to perform the sensitivity analysis according to the quality of studies, because all of them were at high risk of bias.

\section{Authors' conclusions}

Overall, in participants with ischemic stroke, stem cell transplantation was associated with a reduced neurological impairment, but not with a better functional outcome. No obvious safety concerns were raised. However, these conclusions came mostly from small RCTs with high risk of bias, and the certainty of the evidence ranged from low to very low. More well-designed trials are needed.

\section{PLAIN LANGUAGE SUMMARY}

\section{Stem cell transplantation for ischemic stroke}

\section{Review question}

Is stem cell transplantation safe and more effective than conventional treatments in improving recovery after ischemic stroke?

\section{Background}

Stroke represents a leading cause of death and disability worldwide, with very large healthcare and social costs. Available therapies, targeted to restore patency of the blood vessel, consist of intravenous thrombolysis (the breakdown of blood clots formed in blood vessels, using medication) and endovascular mechanical thrombectomy (surgical removal of clot), administrated within a few hours of stroke onset, to just a few selected patients. Preliminary studies of stem cell transplantation (injecting cells that may save or replace damaged nerve tissue) could be safe and effective in ischemic stroke. However, information in humans is lacking. This review updates the previous Cochrane Review on this topic (Boncoraglio 2010).

\section{Study characteristics}

We included randomized trials that recruited adults with ischemic stroke, at any time after onset. We included any kind of stem cell or method of administration.

\section{Key results}

We identified seven randomized trials, involving 401 participants. Overall, stem cell transplantation was associated with a reduced neurological impairment, but not with a better functional outcome. No safety concerns were raised.

\section{Certainty of the evidence}

The certainty of the evidence ranged from low to very low because of the risk of bias in the included studies, the lack of precision of the results, and different designs. More well-designed randomized controlled trials are needed. 
SUMMARY OF FINDINGS

\section{Summary of findings for the main comparison. Stem cell transplantation compared to conventional treatments for ischemic stroke}

Stem cell transplantation compared to conventional treatments for ischemic stroke

Patient or population: ischemic stroke

Setting: hospital

Intervention: stem cell transplantation

Comparison: conventional treatments

\begin{tabular}{|c|c|c|c|c|c|c|c|}
\hline \multirow[t]{2}{*}{ Outcomes } & \multicolumn{3}{|c|}{ Anticipated absolute effects $(95 \% \mathrm{Cl})$} & \multirow{2}{*}{$\begin{array}{l}\text { Relative ef- } \\
\text { fect } \\
(95 \% \mathrm{CI})\end{array}$} & \multirow{2}{*}{$\begin{array}{l}\text { No of Partici- } \\
\text { pants } \\
\text { (studies) }\end{array}$} & \multirow{2}{*}{$\begin{array}{l}\text { Certainty of } \\
\text { the evidence } \\
\text { (GRADE) }\end{array}$} & \multirow[t]{2}{*}{ Comments } \\
\hline & $\begin{array}{l}\text { Without stem } \\
\text { cell trans- } \\
\text { plantation }\end{array}$ & $\begin{array}{l}\text { With stem } \\
\text { cell trans- } \\
\text { plantation }\end{array}$ & Difference & & & & \\
\hline $\begin{array}{l}\text { Neurologic } \\
\text { impairment } \\
\text { (measured by } \\
\text { NIHSS; } 0 \text { to } \\
\text { 42; higher = } \\
\text { worse) }\end{array}$ & $\begin{array}{l}\text { Median score } \\
=5.9\end{array}$ & - & $\begin{array}{l}\text { MD } 1.49 \text { lower } \\
(2.65 \text { lower to } \\
0.33 \text { lower })\end{array}$ & - & $\begin{array}{l}319 \\
\text { (5 RCTs) }\end{array}$ & $\begin{array}{l}\oplus \oplus \ominus \ominus \\
\text { Low } a, b\end{array}$ & $\begin{array}{l}\text { Four studies were at high risk of bias for blinding } \\
\text { of participants and personnel at high risk of bias. } \\
\text { Heterogeneity: } \text { Tau }^{2}=1.13 ; \mathrm{Chi}^{2}=11.68, \mathrm{df}=4(\mathrm{P} \\
=0.02) ; \mathrm{I}^{2}=66 \%\end{array}$ \\
\hline $\begin{array}{l}\text { Disability } \\
\text { (measured } \\
\text { by mRS; } 0 \text { to } \\
6 \text {; higher = } \\
\text { worse) }\end{array}$ & $\begin{array}{l}\text { Median score } \\
=2.75\end{array}$ & - & $\begin{array}{l}\text { MD } 0.42 \text { lower } \\
(0.86 \text { lower to } \\
0.02 \text { higher })\end{array}$ & - & $\begin{array}{l}371 \\
\text { (6 RCTs) }\end{array}$ & $\begin{array}{l}\oplus \odot \Theta \odot \\
\text { Very lowa,b,c }\end{array}$ & $\begin{array}{l}\text { Five studies were at high risk of bias for blinding } \\
\text { of participants and personnel at high risk of bias. } \\
\text { Heterogeneity: } \text { Tau }^{2}=0.19 ; \mathrm{Chi}^{2}=18.12, \mathrm{df}=5 \text { ( } \mathrm{P} \\
=0.003) ; I^{2}=72 \% \text {. The confidence interval was } \\
\text { wide. }\end{array}$ \\
\hline $\begin{array}{l}\text { Dependency } \\
\text { (measured by } \\
\mathrm{BI} ; 0 \text { to } 100 \text {; } \\
\text { higher = bet- } \\
\text { ter) }\end{array}$ & $\begin{array}{l}\text { Median score } \\
=63.39\end{array}$ & - & $\begin{array}{l}\text { MD } 14.09 \\
\text { higher } \\
\text { (1.94 lower to } \\
30.13 \text { higher) }\end{array}$ & - & $\begin{array}{l}170 \\
\text { (3 RCTs) }\end{array}$ & $\begin{array}{l}\oplus \ominus \odot \odot \\
\text { Very lowa,b,c }\end{array}$ & $\begin{array}{l}\text { All studies were at high risk of bias for blinding } \\
\text { of participants and personnel at high risk of bias. } \\
\text { Heterogeneity: } \text { Tau }^{2}=154.96 ; \mathrm{Chi}^{2}=9.04, \mathrm{df}=2 \\
(\mathrm{P}=0.01) ; \mathrm{I}^{2}=78 \% \text {. The confidence interval was } \\
\text { wide and crossed the line of no difference. }\end{array}$ \\
\hline \multirow{2}{*}{$\begin{array}{l}\text { Any cause of } \\
\text { death }\end{array}$} & \multicolumn{3}{|c|}{ Study population } & RR 0.66 & 371 & $\oplus \oplus \ominus \ominus$ & Five studies were at high risk of bias for blinding \\
\hline & $19.7 \%$ & $\begin{array}{l}13.0 \% \\
(7.7 \text { to } 22.4)^{*}\end{array}$ & $\begin{array}{l}\mathbf{6 . 7 \%} \text { fewer } \\
\text { (12 fewer to } \\
2.8 \text { more })\end{array}$ & & & & $\begin{array}{l}\text { The confidence interval was wide and crossed } \\
\text { the line of no difference. }\end{array}$ \\
\hline
\end{tabular}




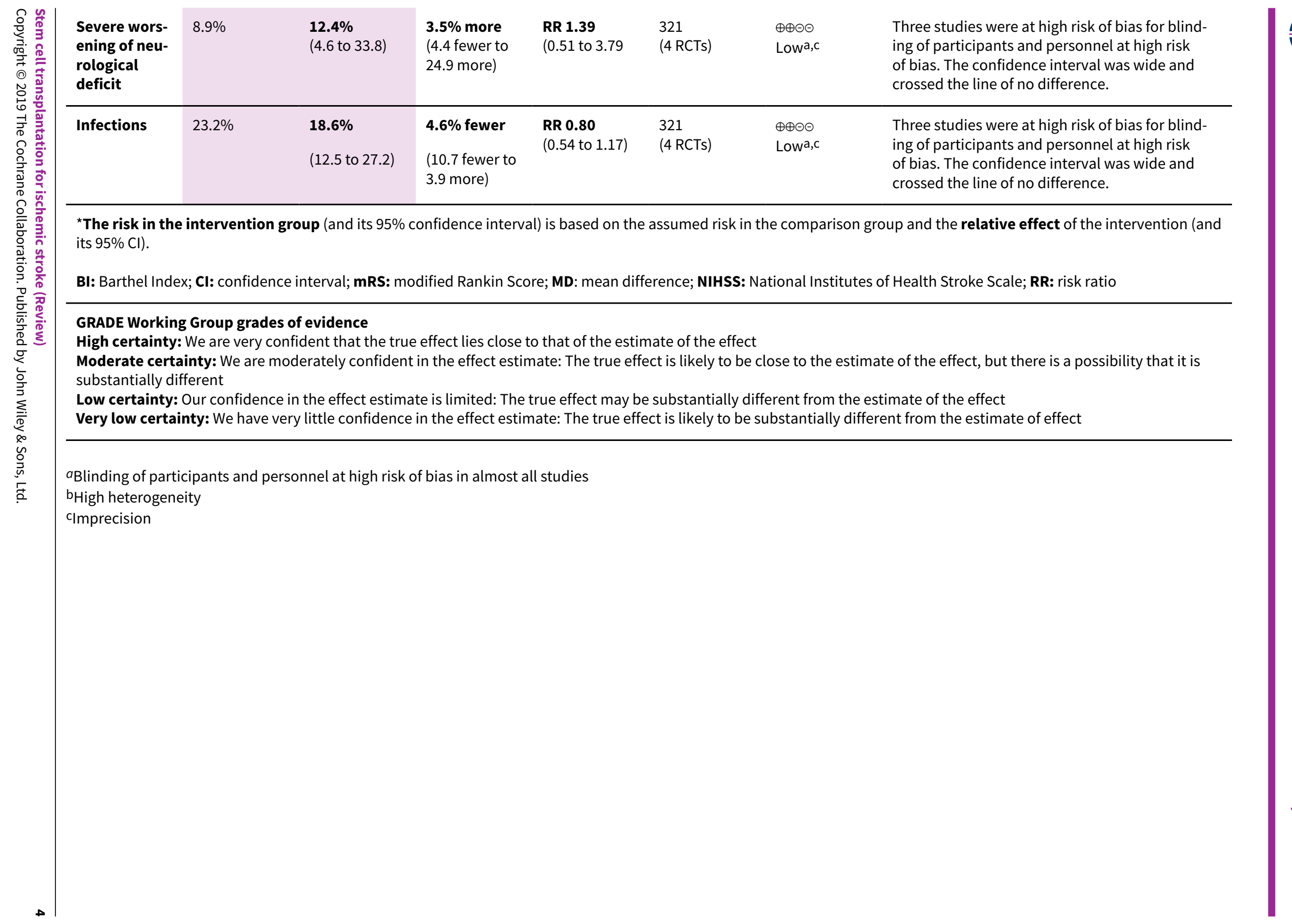




\section{B A C K G R O U N D}

This review is the first update of a previously published review (Boncoraglio 2010).

\section{Description of the condition}

After ischemic heart disease, stroke is the leading cause of morbidity and mortality worldwide (Hankey 2017). About $85 \%$ of strokes are ischemic, caused by the interruption of blood flow in a brain-supplying artery; this leads to irreversible cell damage in the ischemic core, surrounded by a penumbra of surviving neurons. The rescue of the ischemic penumbra influences the functional recovery and represents the target of the available therapies (Hankey 2017; Powers 2018). In the last two decades, with the widespread adoption of organized stroke units, some reperfusion interventions given in the acute phase of ischemic stroke, such as intravenous recombinant tissue plasminogen activator and endovascular mechanical thrombectomy for large artery occlusion, have improved outcomes, including survival and residual disability (Hankey 2017; Powers 2018). However, due to the restricted treatment window and the selection criteria, only a minority of people can benefit from these therapies (de Los Rios la Rosa 2012; Kim 2017). Therefore, once brain damage has occurred, little can be done to improve functional outcome, except for rehabilitation therapy and pharmacological management of comorbidities, with very large healthcare and social costs. To date, the case fatality rate at five years is $50 \%$, and $40 \%$ of stroke survivors are disabled (Hankey 2017), which leads to a strong demand for alternative therapeutic approaches.

\section{Description of the intervention}

Following a large number of experimental studies that highlighted the potential of stem cell transplantation as a novel therapeutic approach for stroke (STEPS 3 2014; Zhang 2009), over the past 15 years, a series of small, safety and feasibility-focused studies have investigated the use of stem cell therapies in people with stroke (Muir 2016). Various sources (xenogeneic, allogenic, or autologous) and types (embryonic or fetal neural, umbilical mesenchymal, bone marrow-derived mesenchymal, or peripheral blood hematopoietic) of stem cells have been evaluated, in different phases of disease (acute, subacute, or chronic), and with different routes of administrations (intravenous, intra-arterial, or intracerebral [Nagpal 2017]). STEPS 3 (Stem cells as an emerging paradigm in stroke 3) provides suggestions to develop phase II/ III clinical trials in acute and chronic stroke (STEPS 3 2014), but currently, exact recommendations about patient selection, cell type and dosing, time window, end-points, and follow-up duration, do not exist.

\section{How the intervention might work}

Preclinical studies have demonstrated that various types of cellbased therapies substantially improve stroke recovery (Zhang 2009). However, during the last 15 years, the understanding of mechanisms of action has significantly advanced: rather than cell replacement, the benefit of stem cell treatments in stroke seems to result from indirect mechanisms, such as immunomodulation, intended to suppress the postischemic inflammatory response, and enhancement of the endogenous repair (Goldman 2016; Janowski 2015; Muir 2016; Zhang 2009). Trial paradigms are now focused on two different approaches: neuroprotection in the acute phase, and neurorestoration in the chronic phase (Borlongan 2016).
The early delivery of cells reduces acute tissue injury, modifying the tissue environment, basically with a paracrine mode of action, for example suppressing oxidative stress, inflammation, mitochondrial impairment, and apoptosis. In acute stroke, patients may be in a critical state, and the minimally invasive intravenous or intra-arterial delivery of stem cells is preferred. Pooled allogenic cells manufactured by the industry are ready to use, and will migrate close to the infarcted area due to peripheral chemoattractants (Borlongan 2016; Muir 2016). Cells with an higher immunomodulating potential, such as mesenchymal stem cells, are usually preferred (Janowski 2015).

A later delivery of cells during the recovery phase, when the chemokine signaling has waned, requires a direct intracerebral implantation close to the damaged areas. Neural stem cells have a higher potential of engraftment within the brain, and are usually preferred in this phase (Janowski 2015). The engraftment is intended to initiate brain remodeling by stimulating quiescent stem cells to mount reparative processes, including angiogenesis, vasculogenesis, neurogenesis, and synaptogenesis (Borlongan 2016; Muir 2016).

\section{Why it is important to do this review}

Stroke is a leading cause of morbidity and mortality worldwide, with very large healthcare and social costs, and there is a strong demand for alternative therapeutic approaches. To date, evidence for the benefit and safety of stem cell transplantation in patients with ischemic stroke is lacking. A systematic review of the available clinical trials is needed to assess the benefit-to-risk profile of stem cell transplantation in people with ischemic stroke compared with control.

\section{O B JECTIVES}

To assess the efficacy and safety of stem cell transplantation compared with control in people with ischemic stroke.

\section{METHODS}

\section{Criteria for considering studies for this review}

\section{Types of studies}

We only included published and unpublished randomized controlled trials (RCTs).

\section{Types of participants}

We included people with ischemic stroke, with an ischemic lesion confirmed by computerized tomography (CT) or magnetic resonance imaging (MRI) scan, in any phase of the disease, from acute to chronic. This long time period allowed for the inclusion of studies investigating both the neuroprotective and neurorestorative effects of transplanted stem cells.

\section{Types of interventions}

We included all types of stem cell transplantation, regardless of cell source, cell type, route of administration, or dosage. We excluded studies with combined treatments. 


\section{Types of outcome measures}

\section{Primary outcomes}

Efficacy (neurologic impairment or functional outcome - disability or dependency, or both) at longer-term follow-up, assessed using clinical outcome measures or validated international scales, for example the National Institutes of Health Stroke Scale (NIHSS), the modified Rankin Scale (mRS), or the Barthel Index (BI). We set six months as the minimum follow-up period.

\section{Secondary outcomes}

We evaluated the following postprocedural safety outcomes:

- any cause of death within 30 days of the procedure, and thereafter;

- severe worsening of neurological deficit (increase of four points on the NIHSS scale or equivalent) within 30 days of procedure, and thereafter;

- infections within 30 days of the procedure, and thereafter;

- neoplastic transformation of ischemic lesion at longer followup.

\section{Search methods for identification of studies}

See the Cochrane Stroke Group's search methods. We searched for trials in all languages and arranged translation of relevant research where necessary.

\section{Electronic searches}

We searched the Cochrane Stroke Group Trials Register, which was last searched by the Information Specialist on 13 August 2018; the Cochrane Central Register of Controlled Trials (CENTRAL; 2018, Issue 7) in the Cochrane Library (searched August 2018; Appendix 1); MEDLINE Ovid (1966 to August 2018; Appendix 2); Embase Ovid (1980 to August 2018; Appendix 3); and BIOSIS Citation Index (1926 to August 2018; Appendix 4).

We also searched the following ongoing trials and research registers in (last searched August 2018):

- US National Institutes of Health Ongoing Trials Register ClinicalTrials.gov (www.clinicaltrials.gov);

- World Health Organization International Clinical Trials Registry Platform (apps.who.int/trialsearch);

- Internet Stroke Center Stroke Trials Registry (www.strokecenter.org/trials/).

\section{Searching other resources}

In an effort to identify further published, unpublished, and ongoing trials we:

- handsearched the conference proceedings;

- screened reference lists of relevant papers;

- contacted individuals active in the field and stem cell manufacturers (Athersys, Celgene Cellular Therapeutics, ReNeuron, SanBio); we last contacted them in August 2018.

\section{Data collection and analysis}

\section{Selection of studies}

Two review authors ( $A B$ and $M R$ ) independently read titles and abstracts (if available) of the identified references and eliminated obviously irrelevant studies. We retrieved full-text articles for the references that remained, and two review authors ( $A B$ and $M R$ ) independently examined potentially relevant studies, using the predetermined criteria of whether:

- the study was a RCT;

- the participants had an ischemic stroke with an ischemic lesion confirmed at neuroimaging, and the intervention was stem cell transplantation;

- neurologic impairment, or disability or dependency, or both, were measured at entry and at the minimum follow-up period of six months, using validated international scales.

We ranked studies as excluded, included, or uncertain, using a checklist. We resolved any disagreements through discussion with a third review author (GBB).

We collected multiple reports on the same study, so that each study, not each reference, was the final unit of interest in the review. We recorded the selection process and completed a PRISMA flow diagram (PRISMA 2009).

\section{Data extraction and management}

Two review authors ( $A B$ and $M R$ ) independently extracted data from the included studies. We resolved discrepancies by discussion. We used a standard data extraction form based on the one recommended by the Cochrane Handbook for Systematic Reviews of Interventions to extract the following information: first study author; year of publication; recruitment period; phase of the disease; sample size; source and type of stem cell transplantation; route of administration; timing of stem cell transplantation; outcome data; and the follow-up period (Higgins 2011).

\section{Assessment of risk of bias in included studies}

Two review authors ( $A B$ and $M R$ ) independently assessed the risk of bias for each study, using the criteria outlined in the Cochrane Handbook for Systematic Reviews of Interventions (Higgins 2011). We resolved disagreements by discussion, or by consultation with another review author (GBB). We assessed risk of bias according to the following domains:

- random sequence generation;

- allocation concealment;

- blinding of participants and personnel;

- blinding of outcome assessment;

- incomplete outcome data;

- selective outcome reporting;

- other bias.

We graded the risk of bias for each domain as high, low, or unclear, and provided information from the study report, together with justification of our judgment, in the 'Risk of bias' tables. 


\section{Measures of treatment effect}

For continuous outcome, we calculated the mean difference (MD) and relative $95 \%$ confidence interval $(\mathrm{Cl})$ for studies using the same scales, and the standardized mean difference (SMD) with its relative $95 \% \mathrm{Cl}$ if different scales were used; for dichotomous outcomes, we calculated the relative risk (RR) and $95 \% \mathrm{Cl}$.

\section{Unit of analysis issues}

The unit of analysis was the participant; we did not include clusterrandomized trials.

\section{Dealing with missing data}

When we found data were missing or identified discrepancies in study publications, we contacted the study authors to request further information. Where intention-to-treat analyses were not possible from the published and unpublished data, we did ontreatment (per protocol) analyses.

\section{Assessment of heterogeneity}

To quantify between-study heterogeneity, we used the $\mathrm{I}^{2}$ statistic. If we found substantial heterogeneity $\left(1^{2}>75 \%\right)$, we explored the reasons.

\section{Assessment of reporting biases}

If we had identified at least 10 studies for each outcome, we would have assessed reporting bias using funnel plots.

\section{Data synthesis}

We combined the study results using a random-effects metaanalysis. We estimated the weighted treatment effect and $95 \% \mathrm{Cl}$ across trials for continuous outcomes, and pooled RR with its $95 \%$ $\mathrm{Cl}$ for dichotomous outcomes. We used Review Manager 5 for all data entry and analysis (RevMan 2014).

\section{Subgroup analysis and investigation of heterogeneity}

For the primary outcomes, we considered the following prespecified subgroups.

- Type of participant:

- phase of disease: acute (within seven days of ischemic stroke), subacute (between eight days and three months), or chronic (more than three months after ischemic stroke).

- Type of treatment:

- source of stem cells: human or nonhuman; embryonic and fetal; or adult, neural, or non-neural;
- route of administration: neurosurgery, intra-arterial, or intravenous.

We considered heterogeneity to be significant if $\mathrm{I}^{2}$ was greater than $75 \%$; if so, we sought the potential reasons, e.g. different follow-up period.

\section{Sensitivity analysis}

To test the robustness of the results, we had intended to undertake a sensitivity analysis by incorporating or removing studies that we assessed to be of lower or ambiguous methodological quality.

\section{Summary of findings table}

We presented the overall certainty of the evidence for efficacy outcomes (neurologic impairment, disability, dependency), any cause of death, severe worsening of neurological deficit, and infections. We evaluted the overall certainty of the evidence according to the GRADE approach (GRADE Working Group 2004). We created the 'Summary of findings' table using GRADEpro GDT (GRADEpro GDT).

\section{RES U L T S}

\section{Description of studies}

See: Characteristics of included studies; Characteristics of excluded studies; Characteristics of studies awaiting classification; Characteristics of ongoing studies.

We included seven randomized trials of 401 participants with acute, subacute, and chronic ischemic stroke, who had been treated with stem cell transplantation.

\section{Results of the search}

We identified 6398 references from electronic databases and through handsearching. Figure 1 shows the PRISMA study flow diagram. Of the 6398 records identified, we removed 751 duplicate references to the same papers. We excluded a further 5560 references because they were not relevant. After full-text review of the remaining 87 references, referring to 74 studies, we excluded 43 studies that did not meet the eligibility criteria (see Excluded studies). For 12 studies that met the inclusion criteria, we were unable to obtain published relevant data; therefore, we contacted authors to obtain additional unpublished data, but we did not receive any replies (see Studies awaiting classification). Twelve studies met the inclusion criteria, but are currently ongoing (See Ongoing studies). Therefore, we included six new studies in this version of the review, along with one trial already included in the previous version, involving 401 participants (Boncoraglio 2010). 
Figure 1. Results of database searches

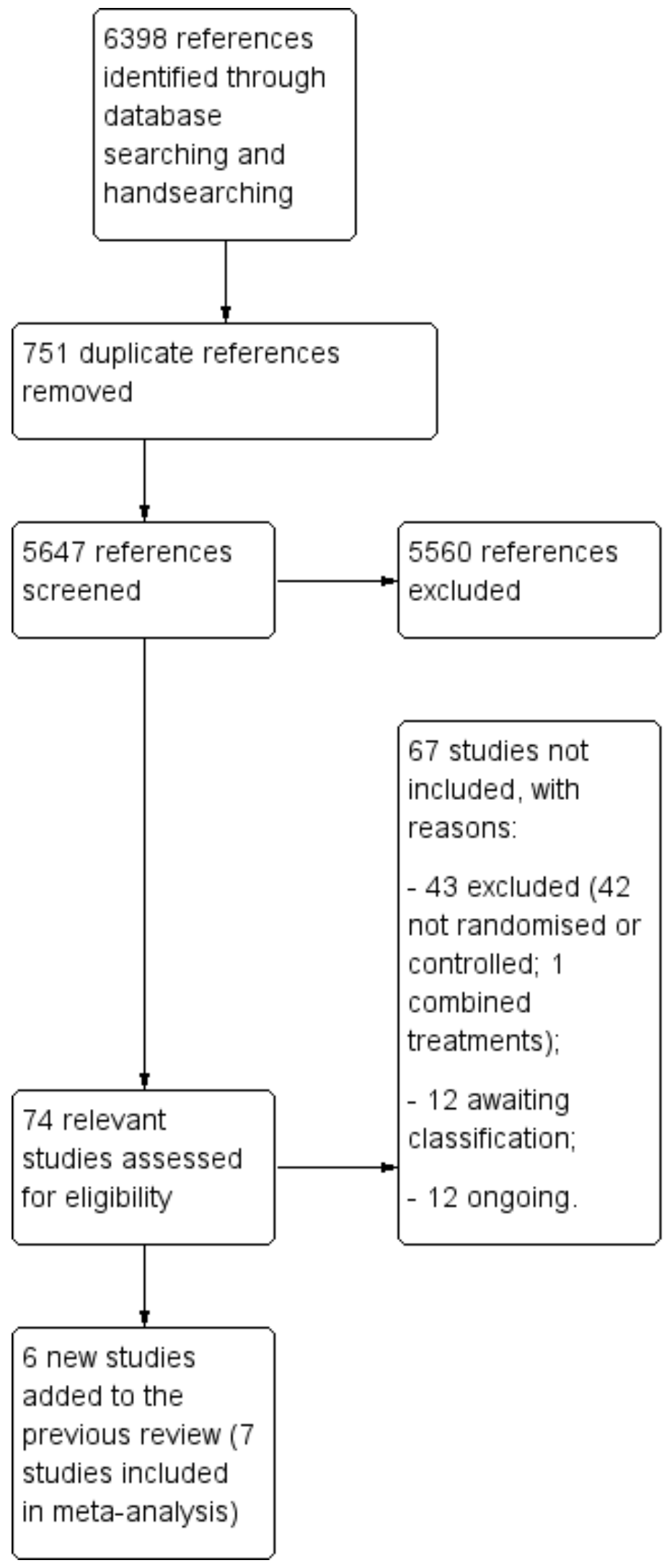




\section{Included studies}

We identified seven trials that fulfilled the inclusion criteria (Bang 2005; Bhatia 2015; Chen 2014; Hess 2014; Jin 2016; Lee 2010; Prasad 2014).

All seven trials used adult human non-neural stem cells: five bone marrow-derived mesenchymal/mononuclear cells (Bang 2005; Bhatia 2015; Jin 2016; Lee 2010; Prasad 2014), one peripheral blood stem cells (Chen 2014), and one multipotent adult progenitor cells (Hess 2014).

In five studies, during the subacute phase, cells were transplanted intravenously (Bang 2005; Lee 2010; Prasad 2014), intra-arterially (Bhatia 2015), or into the lumbar subarachnoid space (Jin 2016). In one study, cells were transplanted intravenously during the acute phase (Hess 2014), and in one study, cells were transplanted intracerebrally during the chronic phase (Chen 2014).

Follow-up ranged from six months (Bhatia 2015), to one year (Bang 2005; Chen 2014; Hess 2014; Prasad 2014), five years (Lee 2010), or seven years (Jin 2016).

Efficacy outcomes were reported using the National Institutes of Health Stroke Scale (NIHSS) in five studies (Bhatia 2015; Chen 2014; Hess 2014; Jin 2016; Prasad 2014), the modified Rankin Scale (mRS) in six studies (Bhatia 2015; Chen 2014; Hess 2014; Jin 2016; Lee 2010; Prasad 2014), and the Barthel Index (BI) in three studies (Bang 2005; Jin 2016; Prasad 2014). Safety outcomes included case fatality at end-of-trial in cases and controls in six studies (Bhatia 2015; Chen 2014; Hess 2014; Jin 2016; Lee 2010; Prasad 2014), neurological deterioration in four studies (Bhatia 2015; Hess 2014; Lee 2010; Prasad 2014), infections in four studies (Bhatia 2015; Hess 2014; Lee 2010; Prasad 2014), and new neoplastic disease in two studies (Bhatia 2015; Lee 2010).

We reported detailed description of the included studies in the Characteristics of included studies.

\section{Excluded studies}

We excluded 43 studies for the reasons described in the Characteristics of excluded studies: 42 were not randomized controlled trials (Banerjee 2014; Battistella 2011; Bhasin 2011; Bhasin 2013; CoBIS 2015; Friedrich 2012; Ghali 2016; Honmou 2011; ISRCTN15677760; Kondziolka 2000; Li 2007; Lin 2008; Lu 2013; Man 2006; Mendonça 2006; Mohamed Ibrahim 2016; Moniche 2012; Napgal 2016; NCT01297413; NCT02397018; NCT02795052; NCT03296618; NCT03384433; PISCES 2016; PISCES II 2017; Prasad 2012; Qiao 2014; Rabinovich 2005; Savitz 2005; Savitz 2011; Sharma 2014; Sinden 2009; Steinberg 2014; Suarez-Monteagudo 2009; Taguchi 2015; Vahidy 2012; Wanamaker 2015; Wang 2007; Wang 2013; Yang 2005; Yang 2007; Zhang 2006), and one evaluated combined treatments (Meng 2009). We did not exclude any study because of the lack of neuroimaging or measurement of the neurological impairment at baseline.

Twelve studies did not publish or provide data relevant for this review (see Characteristics of studies awaiting classification [ChiCTR-INR-16008908; Kondziolka 2005; NCT01310114; NCT01468064; NCT01518231; NCT02378974; NCT02564328; NCT02605707; NCT03176498; NCT03186456; Sych 2012; Yavagal 2015]).

A further 12 studies met the inclusion criteria, but are currently ongoing, and are expected to enroll over 1300 participants (see Characteristics of ongoing studies [Bhasin 2016; Detante 2013; Diez-Tejedor 2014; Honmou 2016; Kim 2013; Moniche 2015; NCT02448641; NCT02580019; NCT03004976; NCT03545607; RESSTORE 2015; TREASURE 2018]).

\section{Risk of bias in included studies}

For full details, see the corresponding 'Risk of bias' tables in Characteristics of included studies, and Figure 2 and Figure 3.

\section{Figure 2. Risk of bias graph: review authors' judgements about each risk of bias item presented as percentages across all included studies}

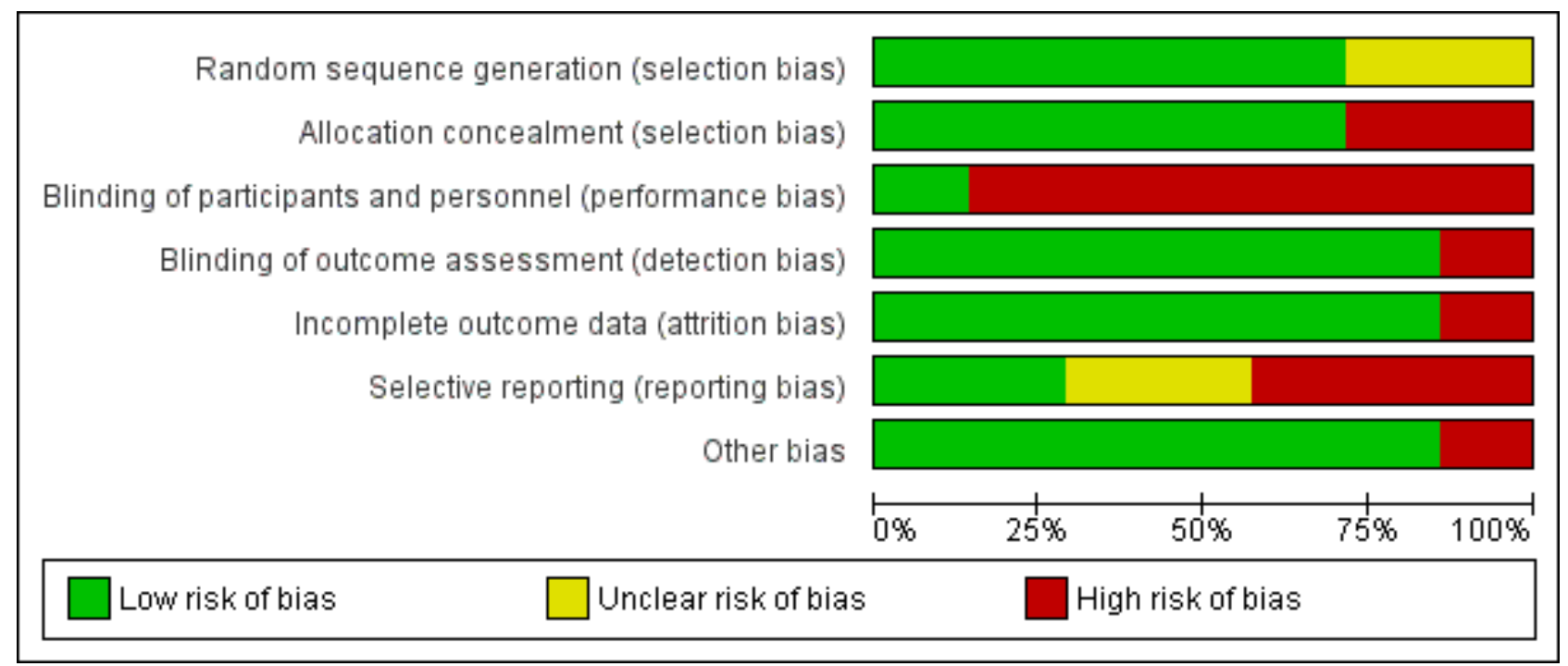


Figure 3. Risk of bias summary: review authors' judgements about each risk of bias item for each included study (green for low risk of bias, yellow for unclear risk of bias, and red for high risk of bias)

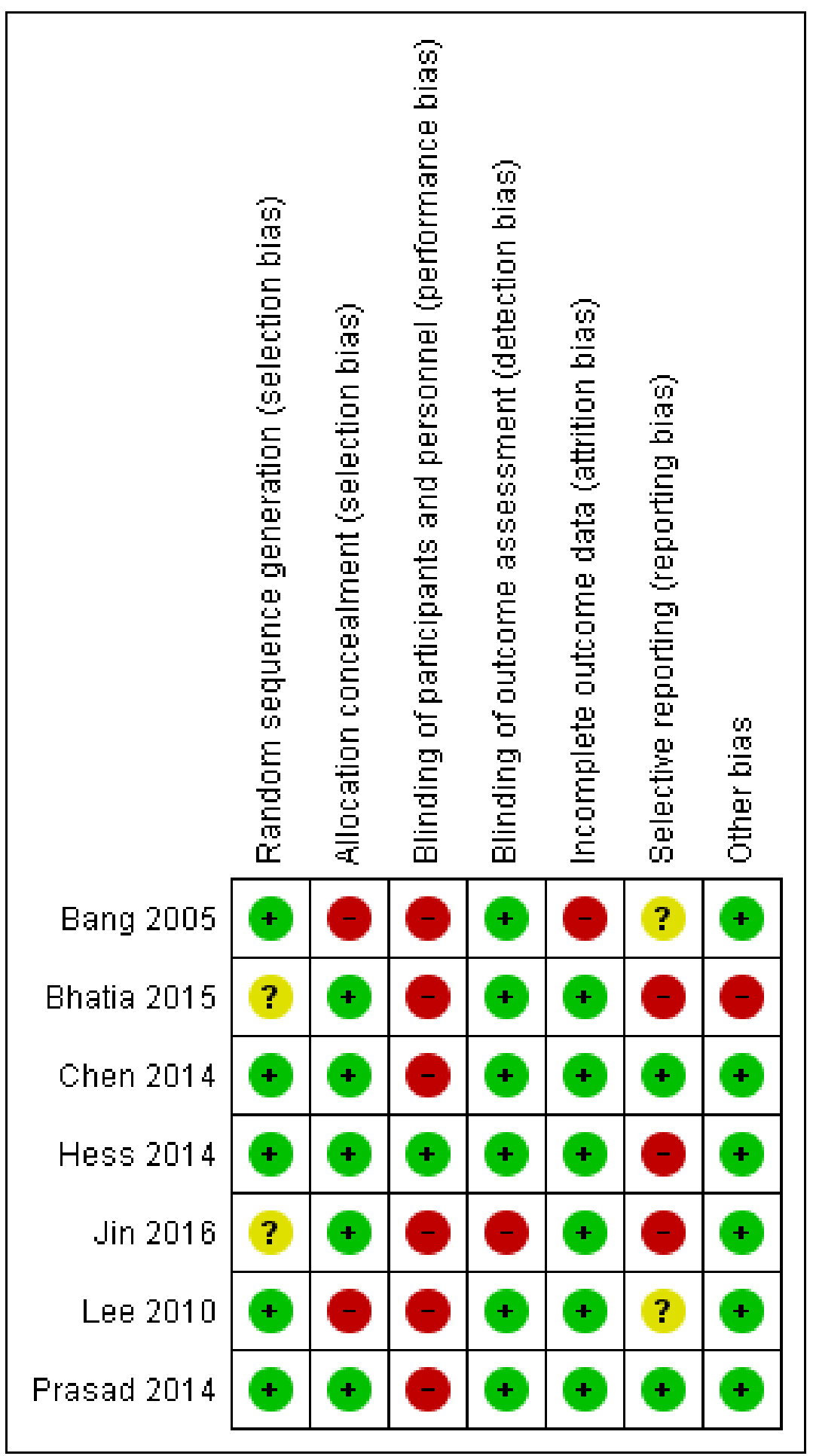

\section{Allocation}

All included trials explicitly stated that randomization occurred. Five trials reported the method of randomization, and we judged them at low risk of bias (Bang 2005; Chen 2014; Hess 2014; Lee 2010; Prasad 2014); two did not report how participants were randomized, and we judged them at unclear risk of bias (Bhatia 2015; Jin 2016)

Allocation was adequately concealed in five trials, and we judged them at low risk of bias (Bhatia 2015; Chen 2014; Hess 2014; Jin 2016; Prasad 2014). In one trial, after initial randomization to the treatment group, five of 15 participants refused, and were 
allocated to the control group (Bang 2005). In one study, after initial randomization, 33 of 85 participants were not included in the study (11 participants died early or underwent hopeless discharge within four weeks after randomization, before the first boosting of stem cells; and 22 were unwilling to participate) without mentioning allocation (Lee 2010). We judged these two trials at high risk of bias.

\section{Blinding}

One trial was blinded to both participants and outcome assessors, and we judged it at low risk of bias (Hess 2014). Due to the invasive procedures required for autologous stem cell transplantation (i.e. bone marrow aspiration or stereotaxic intracerebral implantation), most of the included trails were blinded only to outcome assessors, and not to participants (Bang 2005; Bhatia 2015; Chen 2014; Lee 2010; Prasad 2014). Although this limitation cannot be avoided for ethical reasons, given its possible effect on participants, we assessed these studies at high risk of bias. One trial did not report blinding procedures for either the participants or for the assessors, and we judged it at high risk of bias (Jin 2016).

\section{Incomplete outcome data}

All seven trials reported the numbers lost to follow-up. In one study, $40 \%$ of controls were lost, and we judged the study at high risk of bias (Bang 2005); we judged the remaining six trials at low risk of bias.

\section{Selective reporting}

In two of the included trials, primary outcomes listed in published protocols were adequately reported in the results, and we judged them at low risk of bias (Chen 2014; Prasad 2014). In two trials, the primary outcomes listed in published protocols or interim publications were different from those reported in the results, and we judged them at high risk of bias (Bhatia 2015; Hess 2014). In one trial, the outcomes listed in the methods section were different from those reported in the results, and we judged it at high risk of bias (Jin 2016). In two of the trials, selective reporting bias was not clear because the protocols were not available (Bang 2005; Lee 2010).

\section{Other potential sources of bias}

In one trial, relevant results of 22 participants randomized between day 15 and 28 were not available (Bhatia 2015); the study authors concluded that in this group, intra-arterial infusion of stem cells was safe but without beneficial effect on stroke outcome. However, we considered this a potential bias and judged it at high risk of bias.

In one trial, granulocyte-colony stimulating factor (G-CSF) was used to increase the number of CD34+ peripheral blood stem cells; since G-CSF may be neuroprotective in the acute phase, and this trial included only participants with chronic stroke, this was not considered a potential bias. Therefore, we judged it at low risk of bias (Chen 2014). We did not identify any other potential sources of bias for the remaining five trials, so judged them at low risk of bias.

\section{Effects of interventions}

See: Summary of findings for the main comparison Stem cell transplantation compared to conventional treatments for ischemic stroke

See: Summary of findings for the main comparison

\section{Primary outcomes}

\section{Neurologic impairment}

Five trials, with a total of 319 participants, used the NIHSS to measure this outcome at the end of follow-up (Bhatia 2015; Chen 2014; Hess 2014; Jin 2016; Prasad 2014). Participants randomized to stem cell transplantation had a significantly better outcome compared with controls (mean difference [MD] -1.49, $95 \%$ confidence interval $[\mathrm{Cl}]-2.65$ to $-0.33 ; \mathrm{I}^{2}=66 \%$; low-certainty evidence; Analysis 1.1). In subgroup analysis by phase of disease and route of administration, treatment in the chronic phase of stroke was more effective than in the acute or subacute phase (Analysis 1.2), and neurosurgery (intracerebral or lumbar subarachnoid administration) was more effective than intravenous or intra-arterial administration (Analysis 1.3). However, only one RCT, with 30 or fewer participants, was included in each of these subgroup analyses.

\section{Disability}

Six trials, with a total of 371 participants, used the mRS to measure this outcome at the end of follow-up (Bhatia 2015; Chen 2014; Hess 2014; Jin 2016; Lee 2010; Prasad 2014). Results for participants randomized to stem cell transplantation were inconclusive compared with controls (MD $-0.42,95 \% \mathrm{Cl}-0.86$ to 0.02 ; $1^{2}=72 \%$; very low-certainty evidence; Analysis 1.4$)$. In subgroup analysis by phase of disease and route of administration, treatment during the chronic phase was more effective than treatment during the acute and subacute phase (Analysis 1.5), and neurosurgery (intracerebral or lumbar subarachnoid administration) was more effective than intravenous or intra-arterial administration (Analysis 1.6). However, only one RCT, with 30 or fewer participants, was included in each of these subgroup analyses.

\section{Dependency}

Three trials, with a total of 170 participants, used the BI to measure this outcome at the end of follow-up (Bang 2005; Jin 2016; Prasad 2014 - Analysis 1.7). The results were inconclusive between stem cell transplantation and controls, but the heterogeneity across trials was high (MD $14.09,95 \% \mathrm{Cl}-1.94$ to $30.13,1^{2}=78 \%$; very low-certainty evidence; Analysis 1.7). We found inconclusive results between groups in subgroup analysis by route of administration (Analysis 1.8). In all three trials, participants were treated in the subacute phase.

\section{Secondary outcomes}

\section{Any cause of death}

Death was reported in six trials, with a total of 371 participants (Bhatia 2015; Chen 2014; Hess 2014; Jin 2016; Lee 2010; Prasad 2014). The results were inconclusive between stem cell transplantation and controls (risk ratio [RR] $0.66,95 \% \mathrm{Cl} 0.39$ to $1.14, \mathrm{I}^{2}=0 \%$; Analysis 1.9 )

\section{Severe worsening of neurological deficit}

This outcome was reported in four trials, with a total of 321 participants (Bhatia 2015; Hess 2014; Lee 2010; Prasad 2014). The results were inconclusive between stem cell transplantation and controls (RR 1.39, 95\% Cl 0.51 to $3.79, \mathrm{I}^{2}=41 \%$; Analysis 1.10 ). 


\section{Infections}

This outcome was reported in four trials, with a total of 321 participants (Bhatia 2015; Hess 2014; Lee 2010; Prasad 2014). The results were inconclusive between stem cell transplantation and controls (RR $0.80,95 \% \mathrm{Cl} 0.54$ to $1.17, \mathrm{I}^{2}=0 \%$; Analysis 1.11).

\section{Neoplastic transformation}

This outcome was reported in two trials, with a total of 72 participants (Bhatia 2015; Lee 2010). The results were inconclusive between stem cell transplantation and controls (RR 1.13, 95\% Cl 0.11 to 11.53; Analysis 1.12).

\section{Sensitivity analysis}

We did not perform any sensitivity analyses according to the quality of studies, because all of them were at high risk of bias.

\section{DISCUSSION}

\section{Summary of main results}

We identified seven RCTs, involving 401 participants with ischemic stroke, 188 of whom were treated with stem cell transplantation and 213 of whom were controls. Overall, stem cell transplantation was associated with a better clinical outcome when measured with the National Institutes of Health Stroke Scale (NIHSS), but not with the modified Rankin Scale (mRS) or the Barthel Index (BI). These results could be consistent with a small benefit of stem cell transplantation, which could only be detected when we considered neurological impairment, not when we considered functional outcome. In subgroup analysis by phase of disease and route of administration, treatment during the chronic phase was more effective than treatment during the acute and subacute phase, and neurosurgery (intracerebral or lumbar subarachnoid administration) was more effective than intravenous or intraarterial administration. However, only one RCT, with 30 or fewer participants, was included in each of these subgroup analyses. The high heterogeneity that we found in the primary outcome analysis could be explained by the average high risk of bias (most of the included studies had two or more sources of potential bias) and the different designs (phase of disease, route of administration, and duration of the follow-up) of the included studies.

Of note, two of the included trials, both with the lower risk of bias, treated 60 or more participants each with stem cells (Hess 2014; Prasad 2014), whereas the remaining five trials, with higher risk of bias on average, treated 16 or fewer participants with stem cells. In both larger trials, stem cell transplantation did not significantly influence clinical outcomes, whereas in three of the five smaller trials, it did.

No significant safety concerns associated with stem cell transplantation were raised.

\section{Overall completeness and applicability of evidence}

Our review was deliberately broad, and we sought to include trials in which stem cells were transplanted in people with ischemic stroke so that the review would inform future research. The trials we identified were relevant to our review question. All seven trials used adult human non-neural stem cells, and the results of this review should not be extrapolated to other types of stem cells.

\section{Quality of the evidence}

Overall, five trials reported the method of randomization, five trials adequately concealed the sequence of randomization, and six trials reported that the treatment was blinded to outcome assessors; only one was also blinded to participants. Five trials reported complete outcome data. Selective reporting bias was excluded in only two trials.

Using the GRADE approach, we assessed the certainty of the evidence as low to very low for the primary outcomes. The main reasons for downgrading the certainty of the evidence included risk of bias in included trials, inconsistency, and imprecision.

\section{Potential biases in the review process}

We attempted to limit bias in the review process. This review incorporated extensive literature searches guided by the Cochrane Stroke Group, and we sought unpublished and ongoing work by contacting authors of included studies and other experts in the field. Two review authors independently decided whether studies should be included, and two review authors independently extracted data. During the review process, we did not have any significant disagreement.

In the included studies, there were few missing data, probably with a minimum impact on our conclusions. However, the ongoing trials aim to enroll over 1300 participants, and are likely to have an important influence in future. In the next update, we intend to combine the three types of primary outcome measure into a single primary outcome.

Finally, the mRS is not usually analyzed as a continuous measure, and so the results based on this statistic may be very insensitive.

\section{Agreements and disagreements with other studies or reviews}

Another systematic review, which also included studies without a comparator arm and non-randomized controlled studies, had similar results (Nagpal 2017). Our findings are consistent with previously published papers calling for more research to determine the effectiveness of stem cell transplantation for ischemic stroke.

\section{AUTHORS' CONCLUSIONS}

\section{Implications for practice}

Currently there is insufficient evidence to support or refute the use of stem cell transplantation to treat ischemic stroke.

\section{Implications for research}

Given the high prevalence of long-term disability after stroke, more research is urgently needed to identify new treatments. Stem cells appear promising in animal models, but more well-designed clinical trials are needed (STEPS 3 2014).

\section{ACKNOWLEDGEMENTS}

We are very grateful to Joshua Cheyne of the Cochrane Stroke Group who helped develop the search strategies, and searched the Cochrane Stroke Group Trials Register and the Cochrane Central Register of Controlled Trials. We are grateful to the editors, Peter Langhorne and Paul Nederkoorn, to the Cochrane Stroke Group 
statistician, Aryelly Rodriguez, and to Hilary Carswell and Peng Ooi Cheow for their helpful comments on the review. 


\section{R E F E R E N C E S}

\section{References to studies included in this review}

Bang 2005 \{published and unpublished data\}

Bang OY, Lee JS, Lee PH, Lee G. Autologous mesenchymal stem cell transplantation in stroke patients. Annals of Neurology 2005;57(6):874-82.

\section{Bhatia 2015 \{published and unpublished data\}}

* Bhatia V, Gupta V, Khurana D, Sharma RR, Khandelwal N. Randomized assessment of the safety and efficacy of intraarterial infusion of autologous stem cells in subacute ischemic stroke. American Journal of Neuroradiology 2018;39(5):899-904.

Khurana D, Singh R, Gupta V, Sharma R, Khandelwal N. Safety and efficacy of intra-arterial infusion of bone marrow derived mononuclear cells in subacute ischemic stroke: randomized open labeled clinical trial. European Stroke Journal 2017;2(1S):483.

Singh R, Khurana D, Sharma RR, Gupta V. Safety and clinical outcome of intraarterial infusion of bone marrow derived mononuclear cells in subacute ischemic stroke: randomized open labeled blinded end point clinical pilot trial. European Stroke Journal 2018;3(1S):128.

\section{Chen 2014 \{published data only\}}

Chen DC, Lin SZ, Fan JR, Lin CH, Lee W, Lin CC, et al. Intracerebral implantation of autologous peripheral blood stem cells in stroke patients: a randomized phase II study. Cell Transplantation 2014;23(12):1599-612.

\section{Hess 2014 \{published and unpublished data\}}

Hess DC, Auchus AP, Uchino K, Sila C, Clark WM, Chiu D, et al. Final results of the B01-02 phase 2 trial testing the safety and efficacy of MultiStem in treatment of ischemic stroke. Stroke 2016;47:A71.

Hess DC, Sila CA, Furlan AJ, Wechsler LR, Switzer JA, Mays RW. A double-blind placebo-controlled clinical evaluation of MultiStem for the treatment of ischemic stroke. International Journal of Stroke 2014;9(3):381-6.

* Hess DC, Wechsler LR, Clark WM, Savitz SI, Ford GA, Chiu D, et al. Safety and efficacy of multipotent adult progenitor cells in acute Ischaemic stroke (MASTERS): a randomised, doubleblind, placebo-controlled, phase 2 trial. Lancet Neurology 2017;16(5):360-8.

\section{Jin 2016 \{published data only\}}

Jin Y, Ying L, Yu G, Nan G. Analysis of the long-term effect of bone marrow mononuclear cell transplantation for the treatment of cerebral infarction. International Journal of Clinical and Experimental Medicine 2017;10(2):3059-68.

\section{Lee 2010 \{published data only\}}

Lee JS, Hong JM, Moon GJ, Lee PH, Ahn YH, Bang OY, STARTING Collaborators. A long-term follow-up study of intravenous autologous mesenchymal stem cell transplantation in patients with ischemic stroke. Stem Cells 2010;28(6):1099-106.
Prasad 2014 \{published and unpublished data\}

Prasad K, Sharma A, Garg A, Mohanty S, Bhatnagar S, Johri S, et al. Intravenous autologous bone marrow mononuclear stem cell therapy for ischemic stroke: a multicentric, randomized trial. Stroke 2014;45(12):3618-24.

\section{References to studies excluded from this review}

Banerjee 2014 \{published data only\}

Banerjee S, Bentley P, Hamady M, Marley S, Davis J, Shlebak A, et al. Intra-arterial immunoselected CD34+ stem cells for acute ischemic stroke. Stem Cells Translational Medicine 2014;3(11):1322-30.

\section{Battistella 2011 \{published data only\}}

Battistella V, de Freitas GR, da Fonseca LM, Mercante D, Gutfilen B, Goldenberg RC, et al. Safety of autologous bone marrow mononuclear cell transplantation in patients with non acute ischemic stroke. Regenerative Medicine 2011;6(1):45-52.

Bhasin 2011 \{published data only\}

Bhasin A, Srivastava MV, Kumaran SS, Mohanty S, Bhatia R, Bose $S$, et al. Autologous mesenchymal stem cells in chronic stroke. Cerebrovascular Diseases Extra 2011;1:93-104.

\section{Bhasin 2013 \{published data only\}}

Bhasin A, Srivastava MV, Mohanty S, Bhatia R, Kumaran SS, Bose S. Stem cell therapy: a clinical trial of stroke. Clinical Neurology and Neurosurgery 2013;115(7):1003-8.

\section{CoBIS 2015 \{published data only\}}

Laskowitz DT, Bennett ER, Durham RJ, Volpi JJ, Wiese JR, Frankel M, et al. Allogeneic umbilical cord blood infusion for adults with ischemic stroke: clinical outcomes from a phase 1 safety study. Stem Cells Translational Medicine 2018;7:521-9.

\section{Friedrich 2012 \{published data only\}}

Friedrich MA, Martins MP, Araújo MD, Klamt C, Vedolin L, Garicochea B, et al. Intra-arterial infusion of autologous bone marrow mononuclear cells in patients with moderate to severe middle cerebral artery acute ischemic stroke. Cell Transplantation 2012;21 Suppl 1:S13-21.

\section{Ghali 2016 \{published data only\}}

Ghali AA, Yousef MK, Ragab OA, ElZamarany EA. Intra-arterial infusion of autologous bone marrow mononuclear stem cells in subacute ischemic stroke patients. Frontiers in Neurology 2016;7:228.

\section{Honmou 2011 \{published data only\}}

Honmou O, Houkin K, Matsunaga T, Niitsu Y, Ishiai S, Onodera R, et al. Intravenous administration of auto serumexpanded autologous mesenchymal stem cells in stroke. Brain 2011;134:1790-807.

\section{ISRCTN15677760 \{unpublished data only\}}

ISRCTN15677760. The therapeutic effect of autologous peripheral blood-derived stem cell therapy on acute brain 
infarcts. isrctn.com/ISRCTN15677760 (first received 23 April 2018).

\section{Kondziolka 2000 \{published data only (unpublished sought but not} used)\}

* Kondziolka D, Wechsler L, Goldstein S, Meltzer C, Thulborn KR, Gebel J, et al. Transplantation of cultured human neuronal cells for patients with stroke. Neurology 2000;55(4):565-9.

Meltzer CC, Kondziolka D, Villemagne VL, Wechsler L, Goldstein S, Thulborn KR, et al. Serial [18F] fluorodeoxyglucose positron emission tomography after human neuronal implantation for stroke. Neurosurgery 2001;49(3):586-91.

Nelson PT, Kondziolka D, Wechsler L, Goldstein S, Gebel J, DeCesare $\mathrm{S}$, et al. Clonal human (hNT) neuron grafts for stroke therapy: neuropathology in a patient 27 months after implantation. American Journal of Pathology 2002;160(4):1201-6.

\section{Li 2007 \{published data only\}}

Li JB, Man Y, Shan H, Duan YL. Sterile preparation of umbilical cord derived mesenchymal stem cells with multiple bags: method and effect. Journal of Clinical Rehabilitative Tissue Engineering Research 2007;11(24):4781-4.

Lin 2008 \{published data only\}

Lin SZ, Shyu WC, Li H. CD34+ stem cell therapy in chronic stroke patients - Phase I trial. Cell Transplantation 2008;17(4):472.

\section{Lu 2013 \{published data only\}}

Lu W, Li Z, Tian Z, Jia B, Zeng Y. Clinical transplantation of human embryonic neural stem cells for the treatment of cerebral infarction sequelae. Neurosurgery Quarterly 2013;23(1):58-60.

\section{Man 2006 \{published data only\}}

Man Y, Li J, Yang B, Ma J. Vein transplantation using human umbilical cord blood stem cells in the treatment of stroke sequela. Neural Regeneration Research 2006;1(7):618-21.

\section{Mendonça 2006 \{published data only\}}

Mendez-Otero R, de Freitas GR, André C, de Mendonça ML, Friedrich M, Oliveira-Filho J. Potential roles of bone marrow stem cells in stroke therapy. Regenerative Medicine 2007;2(4):417-23.

* Mendonça ML, Freitas GR, Silva SA, Manfrim A, Falcão CH, Gonzáles $C$, et al. Intra-arterial autologous bone marrow mononuclear cell transplantation for acute ischemic stroke. Arquivos Brasileiros de Cardiologia 2006;86(1):52-5.

\section{Meng 2009 \{published data only\}}

Meng X-G, Zhu S-W, Gao H, Li Z, Shi Q, Hou H-S, et al. Treatment of cerebral infarction using autologous marrow mesenchymal stem cells transplantation: a six-month follow-up. Journal of Clinical Rehabilitative Tissue Engineering Research 2009; Vol. 13, issue 32:6374-8.

\section{Mohamed Ibrahim 2016 \{published data only\}}

Mohamed Ibrahim N, Tan H, Chin S, Law Z, Ismail N, Cheong S, et al. BM-MSC accelerates acute stroke recovery in a randomized placebo-controlled clinical phase II/III study. Cytotherapy 2016;18(6 Supplement):S8.

Moniche 2012 \{published data only\}

* Moniche F, Gonzalez A, Gonzalez-Marcos JR, Carmona M, Piñero $P$, Espigado I, et al. Intra-arterial bone marrow mononuclear cells in ischemic stroke: a pilot clinical trial. Stroke 2012;43(8):2242-4.

Moniche F, Montaner J, Gonzalez-Marcos JR, Carmona M, Piñero P, Espigado I, et al. Intra-arterial bone marrow mononuclear cell transplantation correlates with GM-CSF, PDGF-BB, and MMP-2 serum levels in stroke patients: results from a clinical trial. Cell Transplantation 2014;23 Suppl 1:S57-64.

\section{Napgal 2016 \{published data only\}}

Nagpal A, Kremer KL, Hamilton-Bruce MA, Kaidonis X, Milton AG, Levi $C$, et al. TOOTH (The Open study Of dental pulp stem cell Therapy in Humans): study protocol for evaluating safety and feasibility of autologous human adult dental pulp stem cell therapy in patients with chronic disability after stroke. International Journal of Stroke 2016;11(5):575-85.

NCT01297413 \{unpublished data only\} NCT01297413. A study of allogeneic mesenchymal bone marrow cells in subjects with ischemic stroke. clinicalTrials.gov/show/ NCT01297413 (first received 16 February 2011).

NCT02397018 \{unpublished data only\}

NCT02397018. Cord blood infusion for ischemic stroke. clinicalTrials.gov/show/NCT02397018 (first received 24 March 2015).

NCT02795052 \{unpublished data only\}

NCT02795052. Neurologic Stem cell Treatment study (NEST). clinicalTrials.gov/show/NCT02795052 (first received 9 June 2016).

\section{NCT03296618 \{unpublished data only\}}

NCT03296618. Intracerebral transplantation of neural stem cells for the treatment of ischemic stroke. clinicaltrials.gov/show/ NCT03296618 (first received 28 September 2017).

NCT03384433 \{unpublished data only\}

NCT03384433. Allogenic mesenchymal stem cell derived exosome in patients with acute ischemic stroke. clinicaltrials.gov/show/NCT03384433 (first received 27 December 2017).

PISCES 2016 \{published data only\}

* Kalladka D, Sinden J, Pollock K, Haig C, McLean J, Smith W, et al. Human neural stem cells in patients with chronic ischaemic stroke (PISCES): a phase 1, first-in-man study. Lancet 2016;388(10046):787-96.

Muir KW. Neural stem cells in ischaemic stroke: from bench-tobedside. Journal of Neurology 2012;259 Suppl 1:S109.

PISCES II 2017 \{published data only\}

Bulters D, Wilmot M, Sprigg N, Dixit A, Ward N, Tyrrell P, et al. Ctx human stem cells in stroke recovery: 6 month outcomes of 
the pilot investigation of stem cells in stroke phase 2 efficacy (PISCES II) study. European Stroke Journal 2017;2(1S):484.

Prasad 2012 \{published data only\}

Prasad K, Mohanty S, Bhatia R, Srivastava MV, Garg A, Srivastava $A$, et al. Autologous intravenous bone marrow mononuclear cell therapy for patients with subacute ischaemic stroke: a pilot study. Indian Journal of Medical Research 2012;136(2):221-8.

\section{Qiao 2014 \{published data only\}}

Qiao L, Huang F, Zhao M, Xie J, Shi J, Wang J, et al. A twoyear follow-up study of cotransplantation with neural stem/ progenitor cells and mesenchymal stromal cells in ischemic stroke patients. Cell Transplantation 2014; Vol. 23 Suppl 1:S6572.

\section{Rabinovich 2005 \{published data only\}}

Rabinovich SS, Seledtsov VI, Banul NV, Poveshchenko OV, Senyukov VV, Astrakov SV, et al. Cell therapy of brain stroke. Bulletin of Experimental Biology and Medicine 2005;139(1):126-8.

\section{Savitz 2005 \{published data only\}}

Savitz SI, Dinsmore J, Wu J, Henderson GV, Stieg P, Caplan LR. Neurotransplantation of fetal porcine cells in patients with basal ganglia infarcts: a preliminary safety and feasibility study. Cerebrovascular Diseases 2005;20(2):101-7.

\section{Savitz 2011 \{published data only\}}

Savitz SI, Misra V, Kasam M, Juneja H, Cox CS Jr, Alderman S, et al. Intravenous autologous bone marrow mononuclear cells for ischemic stroke. Annals of Neurology 2011; Vol. 70:59-69.

\section{Sharma 2014 \{published data only\}}

Sharma A, Sane H, Gokulchandran N, Khopkar D, Paranjape A, Sundaram J, et al. Autologous bone marrow mononuclear cells intrathecal transplantation in chronic stroke. Stroke Research and Treatment 2014; Vol. 2014:234095.

\section{Sinden 2009 \{published data only\}}

Sinden J. ReN001, a stem cell therapy for stroke disability. Cell Transplantation 2009;18(2):234.

\section{Steinberg 2014 \{published data only\}}

Steinberg GK, Kondziolka D, Schwartz NE, Wechsler L, Lunsford D, Coburn ML, et al. A novel phase 1/2A study of intraparenchymal transplantation of human modified bone marrow-derived cells in patients with stable ischemic stroke. Cell Transplantation 2014;23(6):784.

* Steinberg GK, Kondziolka D, Wechsler LR, Lunsford LD, Coburn ML, Billigen JB, et al. Clinical outcomes of transplanted modified bone marrow-derived mesenchymal stem cells in stroke: a phase 1/2a study. Stroke 2016;47(7):1817-24.

\section{Suarez-Monteagudo 2009 \{published data only\}}

Suárez-Monteagudo C, Hernández-Ramírez P, AlvarezGonzález L, García-Maeso I, de la Cuétara-Bernal K, Castillo-Díaz L, et al. Autologous bone marrow stem cell neurotransplantation in stroke patients. An open study. Restorative Neurology and Neuroscience 2009;27(3):151-61.

\section{Taguchi 2015 \{published data only\}}

Taguchi A, Sakai C, Soma T, Kasahara Y, Stern DM, Kajimoto K, et al. Intravenous autologous bone marrow mononuclear cell transplantation for stroke: phase $1 / 2$ a clinical trial in a homogeneous group of stroke patients. Stem Cells and Development 2015; Vol. 24, issue 19:2207-18.

Vahidy 2012 \{published data only\}

Vahidy F, Kar S, Aisiku I, Juneja H, Lee D, Garret J, et al. Safety of intravenous mononuclear cells for acute stroke (SIVMAS) trial. Cell Transplantation 2012; Vol. 21 Suppl 1:795.

\section{Wanamaker 2015 \{published data only\}}

Wanamaker CP, Fakhran S, Alhilali LM. Qualitative and quantitative analysis of MR imaging findings in patients with middle cerebral artery stroke implanted with mesenchymal stem cells. American Journal of Neuroradiology 2015;36(6):1063-8.

\section{Wang 2007 \{published data only\}}

Wang YC, Zhang CQ, Wang LZ, Wen H, Yin ZM, Wang L, et al. Autologous bone marrow-derived mononuclear cell transplant for treatment of nervous system damage and degenerative disease: a report of 42 cases. Journal of Clinical Rehabilitative Tissue Engineering Research 2007;11(20):3994-7.

\section{Wang 2013 \{published data only\}}

Wang L, Ji H, Li M, Zhou J, Bai W, Zhong Z, et al. Intrathecal administration of autologous CD34 positive cells in patients with past cerebral infarction: a safety study. ISRN Neurology 2013;2013:128591.

\section{Yang 2005 \{published data only\}}

Yang QC, Zhang XD, Liang CC, Du Y, Li HW. Functional evaluation of stroke patients 6 months after intrathecal injection of neural stem cells. Chinese Journal of Clinical Rehabilitation 2005;9(9):208-10.

\section{Yang 2007 \{published data only\}}

Yang QC, Liang CC, Li MX, Zhang XD, Ma DF. Neural stem cell transplantation for treating stroke sequela in 59 cases. Journal of Clinical Rehabilitative Tissue Engineering Research 2007;11(20):4033-5.

\section{Zhang 2006 \{published data only\}}

Zhang RY, Zheng YR, Hu SS, Cheng HB, An YH. Clinical analysis of neural stem cells for treatment of sequela in 50 stroke patients. Chinese Journal of Clinical Rehabilitation 2006;10(9):138-9.

\section{References to studies awaiting assessment}

ChicTR-INR-16008908 \{unpublished data only\}

ChiCTR-INR-16008908. Allogenic bone marrow-derived mesenchymal stem cells transplantation in severe cerebral infarction patients: a randomized controlled clinical trial. www.chictr.org.cn/showprojen.aspx?proj=14716 (first received 25 July 2016). 
Kondziolka 2005 \{published data only\}

* Kondziolka D, Steinberg GK, Wechsler L, Meltzer CC, Elder E, Gebel J, et al. Neurotransplantation for patients with subcortical motor stroke: a phase 2 randomized trial. Journal of Neurosurgery 2005;103(1):38-45.

Stilley CS, Ryan CM, Kondziolka D, Bender A, DeCesare S, Wechsler L. Changes in cognitive function after neuronal cell transplantation for basal ganglia stroke. Neurology 2004;63(7):1320-2.

\section{NCT01310114 \{unpublished data only\}}

NCT01310114. Study of human placenta-derived cells (PDA001) to evaluate the safety and effectiveness for patients with ischemic stroke. clinicaltrials.gov/show/NCT01310114 (first received 8 March 2011).

\section{NCT01468064 \{unpublished data only\}}

NCT01468064. Autologous bone marrow stromal cell and endothelial progenitor cell transplantation in ischemic stroke (AMETIS). clinicaltrials.gov/show/NCT01468064 (first received 9 November 2011).

\section{NCT01518231 \{unpublished data only\}}

NCT01518231. Autologous hematopoietic stem cell transplantation in ischemic stroke (AHSCTIS). clinicaltrials.gov/ show/NCT01518231 (first received 25 January 2012).

\section{NCT02378974 \{unpublished data only\}}

NCT02378974. Evaluation of the safety and potential therapeutic effects after intravenous transplantation of Cordstem-ST in patients with cerebral infarction. clinicaltrials.gov/show/NCT02378974 (first received 4 March 2015).

\section{NCT02564328 \{unpublished data only\}}

NCT02564328. Autologous bone marrow mesenchymal stem cell transplantation for chronic ischemic stroke. clinicaltrials.gov/show/NCT02564328 (first received 30 September 2015).

\section{NCT02605707 \{unpublished data only\}}

NCT02605707. Autologous endothelial progenitor cells transplantation for chronic ischemic stroke. clinicaltrials.gov/ show/NCT02605707 (first received 16 November 2015).

\section{NCT03176498 \{unpublished data only\}}

NCT03176498. Human umbilical cord mesenchymal stem cell therapy for cerebral infarction patients in convalescent period. clinicaltrials.gov/show/NCT03176498 (first received 5 June 2017).

\section{NCT03186456 \{unpublished data only\}}

NCT03186456. The safety and efficacy of human umbilical cord mesenchymal stem cells in the treatment of acute cerebral infarction. clinicaltrials.gov/show/NCT03186456 (first received 14 June 2017).

\section{Sych 2012 \{published data only\}}

Sych N, Klunnyk M, Ivankova O, Matiyaschuk I. Cognitive functions and S-100 protein in acute brain infarction after fetal stem cells. 8th World Stroke Congress; 2012 Oct 10-13; Brasilia (Brazil). 2012

Yavagal 2015 \{published data only\}

Atchaneeyasakul K, Dharmadhikari S, Sidani C, Ramdas K, Guada L, Pafford R, et al. Intra-arterial ALD401 cell therapy is associated with reduction in stroke volume at 90 days in a subset of the RECOVER-stroke trial. Stroke 2016;47:ATMP32.

* Yavagal DR, Huang DY, Graffagnino C, Rappard G, Budzik R, Likosky W, et al. Intra-arterial delivery of autologous ALDHbr cells in ischemic stroke: final 1-year results of the recover-stroke trial. International Journal of Stroke 2015;10 Suppl 2:1-76.

\section{References to ongoing studies}

Bhasin 2016 \{published data only\}

* Bhasin A, Srivastava MV, Mohanty S, Vivekanandhan S, Sharma S, Kumaran S, et al. Paracrine mechanisms of intravenous bone marrow-derived mononuclear stem cells in chronic ischemic stroke. Cerebrovascular Diseases Extra 2016;6(3):107-19

Bhasin A, Srivastava P, Mohanty S, Subramaniyam V, Kumaran S, Bhatia R. Intravenous bone marrow derived mononuclear stem cells in chronic ischemic stroke-paracrine mechanisms of recovery. Stroke 2016;47 Suppl 1:47 (AWP146).

\section{Detante 2013 \{published data only\}}

Detante O, Jaillard A, Moisan A, Favre I, Barbieux M, Garambois K, et al. Intravenous injection of autologous mesenchymal stem cells after ischemic stroke (ISIS/HERMES): protocol and progress. Cerebrovascular Diseases 2013; Vol. 35 Suppl 3:852.

\section{Diez-Tejedor 2014 \{published data only\}}

Díez-Tejedor E, Gutiérrez-Fernández M, Martínez-Sánchez P, Rodríguez-Frutos B, Ruiz-Ares G, Lara ML, et al. Reparative therapy for acute ischemic stroke with allogeneic mesenchymal stem cells from adipose tissue: a safety assessment: a phase II randomized, double-blind, placebo-controlled, singlecenter, pilot clinical trial. Journal of Stroke and Cerebrovascular Diseases 2014;23(10):2694-700.

Honmou 2016 \{published data only\}

Honmou O. Phase III clinical trial using autologous mesenchymal stem cells for stroke patients. Nihon Rinsho 2016;74(4):649-54.

\section{Kim 2013 \{published data only\}}

Kim SJ, Moon GJ, Chang WH, Kim YH, Bang OY, STARTING-2 (STem cell Application Researches and Trials In NeuroloGy-2) collaborators. Intravenous transplantation of mesenchymal stem cells preconditioned with early phase stroke serum: current evidence and study protocol for a randomized trial. Trials 2013;14:317.

\section{Moniche 2015 \{published data only\}}

Moniche F, Escudero I, Zapata-Arriaza E, Usero-Ruiz M, Prieto-León M, de la Torre J, et al. Intra-arterial bone marrow mononuclear cells (BM-MNCs) transplantation in acute ischemic 
stroke (IBIStrial): protocol of a phase II, randomised, dosefinding, controlled multicenter trial. International Journal of Stroke 2015;10(7):1149-52.

\section{NCT02448641 \{unpublished data only\}}

NCT02448641. Study of modified stem cells (SB623) in patients with chronic motor deficit from ischemic stroke (ACTIsSIMA). clinicaltrials.gov/ct2/show/NCT02448641 (first received 19 May 2015)

\section{NCT02580019 \{unpublished data only\}}

NCT02580019. Umbilical cord derived mesenchymal stem cells treatment in ischemic stroke. clinicaltrials.gov/ct2/show/ NCT02580019 (first received 20 October 2015).

\section{NCT03004976 \{unpublished data only\}}

NCT03004976. Study of allogeneic umbilical cord blood infusion for adults with ischemic stroke (CoBIS 2). clinicaltrials.gov/ show/NCT03004976 (first received 29 December 2016).

\section{NCT03545607 \{unpublished data only\}}

NCT03545607. MultiStem ${ }^{\circledast}$ administration for stroke treatment and enhanced recovery study (MASTERS-2). clinicaltrials.gov/ show/NCT03545607 (first received 4 June 2018).

\section{RESSTORE 2015 \{unpublished data only\}}

REgenerative Stem cell therapy for STroke in Europe.

www.resstore.eu/about-resstore.

\section{TREASURE 2018 \{published data only\}}

Osanai T, Houkin K, Uchiyama S, Minematsu K, Taguchi A, Terasaka S. Treatment evaluation of acute stroke for using in regenerative cell elements (TREASURE) trial: rationale and design. International Journal of Stroke 2018;13(4):444-8.

\section{Additional references}

\section{Borlongan 2016}

Borlongan CV. Age of PISCES: stem-cell clinical trials in stroke. Lancet 2016;388(10046):736-8.

\section{de Los Rios la Rosa 2012}

de Los Ríos la Rosa F, Khoury J, Kissela BM, Flaherty ML, Alwell K, Moomaw CJ, et al. Eligibility for intravenous recombinant tissue-type plasminogen activator within a population: the effect of the European Cooperative Acute Stroke Study (ECASS) III trial. Stroke 2012;43(6):1591-5.

\section{Goldman 2016}

Goldman SA. Stem and progenitor cell-based therapy of the central nervous system: hopes, hype, and wishful thinking. Cell Stem Cell 2016;18(2):174-88.

\section{GRADE Working Group 2004}

GRADE Working Group. Grading quality of evidence and strength of recommendations. BMJ 2004;328(7454):1490-4.

\section{GRADEpro GDT [Computer program]}

McMaster University (developed by Evidence Prime). GRADEpro GDT. Version (accessed 1 October 2018). Hamilton (ON): McMaster University (developed by Evidence Prime), 2015.

\section{Hankey 2017}

Hankey GJ. Stroke. Lancet 2017;389(10069):641-54.

\section{Higgins 2011}

Higgins JPT, Green S, editor(s). Cochrane Handbook for Systematic Reviews of Interventions Version 5.1.0 (updated March 2011). The Cochrane Collaboration, 2011. Available from handbook.cochrane.org.

\section{Janowski 2015}

Janowski M, Wagner DC, Boltze J. Stem cell-based tissue replacement after stroke: factual necessity or notorious fiction?. Stroke 2015;46(8):2354-63.

\section{Kim 2017}

Kim JT, Fonarow GC, Smith EE, Reeves MJ, Navalkele DD, Grotta JC, et al. Treatment with tissue plasminogen activator in the golden hour and the shape of the 4.5-hour time-benefit curve in the National United States Get With The GuidelinesStroke Population. Circulation 2017;135(2):128-39.

\section{Muir 2016}

Muir KW. Clinical trial design for stem cell therapies in stroke: what have we learned?. Neurochemistry International 2017;106:108-13.

\section{Nagpal 2017}

Nagpal A, Choy FC, Howell S, Hillier S, Chan F, HamiltonBruce MA, et al. Safety and effectiveness of stem cell therapies in early-phase clinical trials in stroke: a systematic review and meta-analysis. Stem Cell Research and Therapy 2017;8(1):191.

\section{Powers 2018}

Powers WJ, Rabinstein AA, Ackerson T, Adeoye OM, Bambakidis NC, Becker K, American Heart Association Stroke Council. 2018 guidelines for the early management of patients with acute ischemic stroke: a guideline for healthcare professionals from the American Heart Association/American Stroke Association. Stroke 2018;49(3):e46-110.

\section{PRISMA 2009}

Moher D, Liberati A, Tetzlaff J, Altman DG, PRISMA Group. Preferred reporting items for systematic reviews and metaanalyses: the PRISMA statement. BMJ 2009;339:b2535.

\section{RevMan 2014 [Computer program]}

Nordic Cochrane Centre, The Cochrane Collaboration. Review Manager 5 (RevMan 5). Version 5.3. Copenhagen: Nordic Cochrane Centre, The Cochrane Collaboration, 2014.

\section{STEPS 32014}

Savitz SI, Cramer SC, Wechsler L, STEPS 3 Consortium. Stem cells as an emerging paradigm in stroke 3: enhancing the development of clinical trials. Stroke 2014;45(2):634-9. 


\section{Zhang 2009}

Zhang ZG, Chopp M. Neurorestorative therapies for stroke: underlying mechanisms and translation to the clinic. Lancet Neurology 2009;8(5):491-500.

\section{References to other published versions of this review Boncoraglio 2008}

Boncoraglio GB, Bersano A, Candelise L, Reynolds BA, Parati EA. Stem cell transplantation for ischemic stroke.

\section{CHARACTERISTICS OF STUDIES}

Characteristics of included studies [ordered by study ID]

\section{Bang 2005}

\begin{tabular}{ll}
\hline Methods & Single-blind, randomized, controlled, phase I/II clinical trial \\
\hline Participants & 30 participants with subacute cerebral infarction in the MCA territory and severe neurological deficit \\
& Treatment 10, control 20 \\
& Treated between 32 and 61 days from stroke onset \\
\hline Interventions & $\begin{array}{l}\text { Intravenous infusion of } 2 \text { boosts of } 50 \text { million culture-expanded autologous bone marrow mesenchy- } \\
\text { mal stem cells }\end{array}$ \\
\hline Outcomes & $\begin{array}{l}\text { NIHSS score as an index of neurological deficit and BI and mRS as indices of functional recovery at the } \\
\text { end of the } 12 \text {-month follow-up }\end{array}$
\end{tabular}

Notes

Corresponding author provided individual level data for $\mathrm{BI}$ at 12 months

\section{Risk of bias}

\begin{tabular}{|c|c|c|}
\hline Bias & Authors' judgement & Support for judgement \\
\hline $\begin{array}{l}\text { Random sequence genera- } \\
\text { tion (selection bias) }\end{array}$ & Low risk & $\begin{array}{l}\text { Participants were randomly allocated by a blinded, independent co-ordinator, } \\
\text { using a randomization table }\end{array}$ \\
\hline $\begin{array}{l}\text { Allocation concealment } \\
\text { (selection bias) }\end{array}$ & High risk & $\begin{array}{l}\text { After initial randomization, } 5 \text { participants allocated to the mesenchymal stem } \\
\text { cell group 'refused' and were allocated to the control group }\end{array}$ \\
\hline $\begin{array}{l}\text { Blinding of participants } \\
\text { and personnel (perfor- } \\
\text { mance bias) } \\
\text { All outcomes }\end{array}$ & High risk & Experimental procedures, such as bone marrow aspiration, were not blinded \\
\hline $\begin{array}{l}\text { Blinding of outcome as- } \\
\text { sessment (detection bias) } \\
\text { All outcomes }\end{array}$ & Low risk & $\begin{array}{l}\text { Neurological and functional outcomes were checked by a neurologist who was } \\
\text { blind to the group allocation and radiological data }\end{array}$ \\
\hline $\begin{array}{l}\text { Incomplete outcome data } \\
\text { (attrition bias) } \\
\text { All outcomes }\end{array}$ & High risk & 8 participants from the control group were lost to follow-up at 6 months \\
\hline $\begin{array}{l}\text { Selective reporting (re- } \\
\text { porting bias) }\end{array}$ & Unclear risk & Protocol was not available \\
\hline
\end{tabular}


Bang 2005 (Continued)
Other bias
Low risk
Control participants were significantly younger than those of the mesenchy-
mal stem cell group

Bhatia 2015

\begin{tabular}{|c|c|}
\hline Methods & Single-blind, randomized, controlled clinical trial \\
\hline \multirow[t]{3}{*}{ Participants } & 20 participants with subacute ischemic stroke in the MCA territory and NIHSS > 7 \\
\hline & Treatment 10, control 10 \\
\hline & Treated between 8 and 15 days from stroke onset \\
\hline Interventions & $\begin{array}{l}\text { Intra-arterial infusion of bone marrow-derived mononuclear cells (mean } 6.1 \text { million) into the ipsilateral } \\
\text { MCA }\end{array}$ \\
\hline Outcomes & $\begin{array}{l}\text { Primary safety outcomes and secondary efficacy endpoints as combined mRS, BI, and NIHSS score at } \\
\text { the end of the 6-month follow-up }\end{array}$ \\
\hline Notes & Corresponding author provided individual level data for NIHSS and mRS at 6 months \\
\hline & $\begin{array}{l}\text { In a second arm of the study, } 22 \text { participants were randomized between day } 15 \text { and } 28 \text {; for these partici- } \\
\text { pants, relevant results were not available and therefore, were excluded from the analysis }\end{array}$ \\
\hline
\end{tabular}

\section{Risk of bias}

\begin{tabular}{|c|c|c|}
\hline Bias & Authors' judgement & Support for judgement \\
\hline $\begin{array}{l}\text { Random sequence genera- } \\
\text { tion (selection bias) }\end{array}$ & Unclear risk & $\begin{array}{l}\text { Participants were randomized, but the method of the random sequence gen- } \\
\text { eration was not specified }\end{array}$ \\
\hline $\begin{array}{l}\text { Allocation concealment } \\
\text { (selection bias) }\end{array}$ & Low risk & Participants were correctly allocated \\
\hline $\begin{array}{l}\text { Blinding of participants } \\
\text { and personnel (perfor- } \\
\text { mance bias) } \\
\text { All outcomes }\end{array}$ & High risk & Experimental procedures, such as bone marrow aspiration, were not blinded \\
\hline $\begin{array}{l}\text { Blinding of outcome as- } \\
\text { sessment (detection bias) } \\
\text { All outcomes }\end{array}$ & Low risk & $\begin{array}{l}\text { An experienced neurologist, blinded to the nature of intervention, did the clini- } \\
\text { cal evaluations }\end{array}$ \\
\hline $\begin{array}{l}\text { Incomplete outcome data } \\
\text { (attrition bias) } \\
\text { All outcomes }\end{array}$ & Low risk & Outcome data were complete \\
\hline $\begin{array}{l}\text { Selective reporting (re- } \\
\text { porting bias) }\end{array}$ & High risk & $\begin{array}{l}\text { Primary outcomes listed in interim publications were different from those re- } \\
\text { ported in the results }\end{array}$ \\
\hline Other bias & High risk & $\begin{array}{l}\text { Relevant results of the } 22 \text { participants randomized between day } 15 \text { and } 28 \\
\text { were not available }\end{array}$ \\
\hline
\end{tabular}


Chen 2014

\begin{tabular}{ll}
\hline Methods & Single-blind, randomized, controlled clinical trial \\
\hline Participants & $\begin{array}{l}\text { Treatment } 15, \text { participants with chronic MCA infarction and neurological deficits of intermediate severity } \\
\text { Treated between } 6 \text { months and } 5 \text { years from stroke onset }\end{array}$ \\
\hline Interventions & $\begin{array}{l}\text { Subcutaneous granulocyte-colony stimulating factor injections }(15 \mu \mathrm{gg} / \mathrm{kg} / \text { day) for } 5 \text { consecutive days, } \\
\text { followed by stereotaxic implantation of autologous } 3 \text { to } 8 \text { million CD34+ immunosorted peripheral } \\
\text { blood stem cells }\end{array}$ \\
\hline Outcomes & $\begin{array}{l}\text { Improvements in stroke scales (NIHSS, European Stroke Scale, and European Stroke Scale Motor Sub- } \\
\text { scale) and functional outcomes measure (mRS) from baseline to the end of the 12-month follow-up }\end{array}$ \\
\hline Notes & None \\
\hline
\end{tabular}

\title{
Risk of bias
}

\begin{tabular}{|c|c|c|}
\hline Bias & Authors' judgement & Support for judgement \\
\hline $\begin{array}{l}\text { Random sequence genera- } \\
\text { tion (selection bias) }\end{array}$ & Low risk & $\begin{array}{l}\text { Participants were assigned randomly (1:1) via SAS software to either the pe- } \\
\text { ripheral blood stem cells or the control groups }\end{array}$ \\
\hline $\begin{array}{l}\text { Allocation concealment } \\
\text { (selection bias) }\end{array}$ & Low risk & Participants were correctly allocated \\
\hline $\begin{array}{l}\text { Blinding of participants } \\
\text { and personnel (perfor- } \\
\text { mance bias) } \\
\text { All outcomes }\end{array}$ & High risk & Experimental procedures (such as stereotaxic implantation) were not blinded \\
\hline $\begin{array}{l}\text { Blinding of outcome as- } \\
\text { sessment (detection bias) } \\
\text { All outcomes }\end{array}$ & Low risk & $\begin{array}{l}\text { All clinical information was assessed by clinician raters in a single-blinded } \\
\text { fashion (at clinical evaluation, each participant wore a hat to mask the surgical } \\
\text { scar on their skull) }\end{array}$ \\
\hline $\begin{array}{l}\text { Incomplete outcome data } \\
\text { (attrition bias) } \\
\text { All outcomes }\end{array}$ & Low risk & Outcome data were complete \\
\hline $\begin{array}{l}\text { Selective reporting (re- } \\
\text { porting bias) }\end{array}$ & Low risk & $\begin{array}{l}\text { Primary outcomes listed in published protocols were adequately reported in } \\
\text { the results }\end{array}$ \\
\hline Other bias & Low risk & $\begin{array}{l}\text { Granulocyte-colony stimulating factor may be neuroprotective in the acute } \\
\text { phase, but this trial included participants treated between } 6 \text { months and } 5 \\
\text { years from stroke onset }\end{array}$ \\
\hline
\end{tabular}

Hess 2014

$\begin{array}{ll}\text { Methods } & \text { Double-blind, randomized, placebo-controlled, phase II multicenter dose-escalation clinical trial. } \\ \text { Analysis was by intention-to-treat }\end{array}$

Participants

\begin{abstract}
After safety assessments in 8 participants ( 6 treated with 400 million intravenous multipotent adult progenitor cells, 2 with placebo), 129 participants with acute ischemic stroke involving MCA territory, with NIHSS score 8 to 20 , and infarct size between 5 and $100 \mathrm{cc}^{3}$, were enrolled
\end{abstract}


Hess 2014 (Continued)

Treatment 67, control 62

Treated between 24 and 48 hours from stroke onset

\begin{tabular}{ll}
\hline Interventions & Intravenous infusion of 1.200 million multipotent progenitor cells or placebo \\
\hline Outcomes & $\begin{array}{l}\text { The primary efficacy endpoint combined the } \mathrm{mRS} \text {, the } \mathrm{BI} \text {, and change in NIHSS score from baseline, } \\
\text { and was evaluated at day } 90 \text {, and at the end of the } 12 \text {-month follow-up }\end{array}$
\end{tabular}

Notes

Corresponding author provided summary statistics for NIHSS and mRS at 12 months

\section{Risk of bias}

\begin{tabular}{|c|c|c|}
\hline Bias & Authors' judgement & Support for judgement \\
\hline $\begin{array}{l}\text { Random sequence genera- } \\
\text { tion (selection bias) }\end{array}$ & Low risk & $\begin{array}{l}\text { Computer-generated randomization, interactive voice and web-response sys- } \\
\text { tem }\end{array}$ \\
\hline $\begin{array}{l}\text { Allocation concealment } \\
\text { (selection bias) }\end{array}$ & Low risk & Participants were correctly allocated \\
\hline $\begin{array}{l}\text { Blinding of participants } \\
\text { and personnel (perfor- } \\
\text { mance bias) } \\
\text { All outcomes }\end{array}$ & Low risk & Participants and all trial personnel were blinded \\
\hline $\begin{array}{l}\text { Blinding of outcome as- } \\
\text { sessment (detection bias) } \\
\text { All outcomes }\end{array}$ & Low risk & Investigators and clinicians were blinded \\
\hline $\begin{array}{l}\text { Incomplete outcome data } \\
\text { (attrition bias) } \\
\text { All outcomes }\end{array}$ & Low risk & $\begin{array}{l}\text { Primary outcomes within day } 90 \text { were complete; at 1-year follow-up, } 24 \text { partic- } \\
\text { ipants were lost ( } 9 \text { treatment and } 15 \text { placebo) }\end{array}$ \\
\hline $\begin{array}{l}\text { Selective reporting (re- } \\
\text { porting bias) }\end{array}$ & High risk & $\begin{array}{l}\text { Primary outcomes listed in published protocols were different from those re- } \\
\text { ported in the results }\end{array}$ \\
\hline Other bias & Low risk & $\begin{array}{l}\text { Intravenous tissue-plasminogen activator and endovascular thrombectomy } \\
\text { were more frequent in the placebo group; mean baseline infarct size was larg- } \\
\text { er in the placebo group }\end{array}$ \\
\hline
\end{tabular}

Jin 2016

\begin{tabular}{ll}
\hline Methods & Randomized, controlled clinical trial \\
\hline Participants & 20 participants with subacute cerebral infarction and NIHSS score between 5 and 30 \\
& Treatment 10, control 10 \\
& Treated between 3 weeks and 5 months from stroke onset \\
\hline Interventions & $\begin{array}{l}\text { Subarachnoid infusion of a cell suspension containing } 10 \text { million autologous bone marrow mononu- } \\
\text { clear cells }\end{array}$ \\
\hline Outcomes & Various safety and efficacy outcomes through a 7-year follow-up \\
\hline
\end{tabular}


Jin 2016 (Continued)

Notes None

\section{Risk of bias}

\begin{tabular}{|c|c|c|}
\hline Bias & Authors' judgement & Support for judgement \\
\hline $\begin{array}{l}\text { Random sequence genera- } \\
\text { tion (selection bias) }\end{array}$ & Unclear risk & $\begin{array}{l}\text { Participants were randomized, but the method of the random sequence gen- } \\
\text { eration was not specified }\end{array}$ \\
\hline $\begin{array}{l}\text { Allocation concealment } \\
\text { (selection bias) }\end{array}$ & Low risk & Participants were correctly allocated \\
\hline $\begin{array}{l}\text { Blinding of participants } \\
\text { and personnel (perfor- } \\
\text { mance bias) } \\
\text { All outcomes }\end{array}$ & High risk & Experimental procedures, such as bone marrow aspiration, were not blinded \\
\hline $\begin{array}{l}\text { Blinding of outcome as- } \\
\text { sessment (detection bias) } \\
\text { All outcomes }\end{array}$ & High risk & Not specified \\
\hline $\begin{array}{l}\text { Incomplete outcome data } \\
\text { (attrition bias) } \\
\text { All outcomes }\end{array}$ & Low risk & Outcome data were complete \\
\hline $\begin{array}{l}\text { Selective reporting (re- } \\
\text { porting bias) }\end{array}$ & High risk & $\begin{array}{l}\text { Outcomes listed in the methods section did not correspond with those report- } \\
\text { ed in the results, and NIHSS score reported in text and tables were different }\end{array}$ \\
\hline Other bias & Low risk & None \\
\hline
\end{tabular}

Lee 2010

\begin{tabular}{ll}
\hline Methods & Single-blind, randomized, controlled clinical trial \\
\hline Participants & 52 participants with MCA territory infarct and severe neurological deficit \\
& Treatment 16, control 36 \\
& Treated between 4 and 9 weeks from stroke onset \\
\hline Interventions & $\begin{array}{l}\text { Intravenous infusion of } 2 \text { boosts of } 50 \text { million culture-expanded autologous bone marrow mesenchy- } \\
\text { mal stem cells }\end{array}$ \\
\hline Outcomes & mRS for functional recovery at the end of the 12-month follow-up \\
\hline Notes & None \\
\hline Risk of bias & Authors' judgement Support for judgement \\
\hline Bias & Low risk Participants were randomly allocated by a blinded, independent co-ordinator, \\
\hline $\begin{array}{l}\text { Random sequence genera- } \\
\text { tion (selection bias) }\end{array}$ & using a randomization table \\
\hline
\end{tabular}


Lee 2010 (Continued)

Allocation concealment High risk After initial random allocation of 85 participants to treatment groups, 11 par(selection bias) ticipants died or underwent hopeless discharge, and 22 refused, without reporting allocation

Experimental procedures, such as bone marrow aspiration, were not blinded and personnel (perfor-

mance bias)

All outcomes

Blinding of outcome as- Low risk sessment (detection bias)

All outcomes
The outcome was evaluated separately, by one of the authors who was blinded to clinical information

Incomplete outcome data Low risk $\quad$ Outcome data were complete
(attrition bias)

All outcomes

\begin{tabular}{lll}
$\begin{array}{l}\text { Selective reporting (re- } \\
\text { porting bias) }\end{array}$ & Unclear risk & Protocol was not available \\
\hline Other bias & Low risk & None \\
\hline
\end{tabular}

\section{Prasad 2014}

\begin{tabular}{ll}
\hline Methods & Single-blind, randomized, controlled clinical trial \\
\hline Participants & 120 participants with anterior circulation ischemic stroke \\
& Treatment 60, control 60 \\
Treated between 7 and 30 days from stroke onset
\end{tabular}

\begin{tabular}{ll}
\hline Interventions & Intravenous infusion of a mean of 280 million autologous bone marrow mononuclear stem cells \\
\hline Outcomes & $\begin{array}{l}\text { The primary efficacy endpoint were the mRS and the BI at day } 180 ; \text { NIHSS at day } 365 \text { was a secondary } \\
\text { outcome. The safety outcomes included death, adverse events (serious and non-serious), epileptiform } \\
\text { discharges in electroencephalography, and evidence of any new growth on PET scan at day } 365\end{array}$
\end{tabular}

Notes Corresponding author provided data for NIHSS and mRS at 12 months

\section{Risk of bias}

\begin{tabular}{lll}
\hline Bias & Authors' judgement & Support for judgement \\
\hline $\begin{array}{l}\text { Random sequence genera- } \\
\text { tion (selection bias) }\end{array}$ & Low risk & $\begin{array}{l}\text { Participants were randomly assigned by a central computer, using permuted } \\
\text { block randomization in a 1:1 ratio }\end{array}$ \\
\hline $\begin{array}{l}\text { Allocation concealment } \\
\text { (selection bias) }\end{array}$ & Low risk & $\begin{array}{l}\text { After initial randomization, 2 participants allocated to bone marrow mononu- } \\
\text { clear stem cell group were not treated (1 participant withdrew and 1 partici- } \\
\text { pant was missed because of logistical difficulty) }\end{array}$ \\
$\begin{array}{l}\text { Blinding of participants } \\
\text { and personnel (perfor- } \\
\text { mance bias) }\end{array}$ & High risk & Experimental procedures, such as bone marrow aspiration, were not blinded \\
$\begin{array}{l}\text { All outcomes } \\
\end{array}$ & \\
\hline
\end{tabular}


Prasad 2014 (Continued)

\begin{tabular}{|c|c|c|}
\hline $\begin{array}{l}\text { Blinding of outcome as- } \\
\text { sessment (detection bias) }\end{array}$ & Low risk & $\begin{array}{l}\text { Follow up for all participants was done from the co-ordinating center, by a } \\
\text { trained and blinded assessor, unaware of participant group }\end{array}$ \\
\hline
\end{tabular}

All outcomes

\section{Incomplete outcome data Low risk \\ (attrition bias) \\ 1 treated participant and 1 control were lost at longer follow-up}

All outcomes

\begin{tabular}{ll}
\hline $\begin{array}{l}\text { Selective reporting (re- } \\
\text { porting bias) }\end{array}$ & Low risk \\
& the results
\end{tabular}

\begin{tabular}{ll}
\hline Other bias $\quad$ Low risk & $\begin{array}{l}\text { Infarct volume at baseline was higher in control arm than in bone marrow } \\
\text { mononuclear stem cell arm }\end{array}$
\end{tabular}

BI: Barthel Index

MCA: middle cerebral artery

mRS: modified Rankin Score

NIHSS: National Institutes of Health Stroke Scale

PET: positron emission tomography

Characteristics of excluded studies [ordered by study ID]

\begin{tabular}{|c|c|}
\hline Study & Reason for exclusion \\
\hline Banerjee 2014 & Not RCT \\
\hline Battistella 2011 & Not RCT \\
\hline Bhasin 2011 & Not RCT \\
\hline Bhasin 2013 & Not RCT \\
\hline CoBIS 2015 & Not RCT \\
\hline Friedrich 2012 & Not RCT \\
\hline Ghali 2016 & Not RCT \\
\hline Honmou 2011 & Not RCT \\
\hline ISRCTN15677760 & Not RCT \\
\hline Kondziolka 2000 & Not RCT \\
\hline Li 2007 & Not RCT \\
\hline Lin 2008 & Not RCT \\
\hline Lu 2013 & Not RCT \\
\hline Man 2006 & Not RCT \\
\hline Mendonça 2006 & Not RCT \\
\hline
\end{tabular}




\begin{tabular}{|c|c|}
\hline Study & Reason for exclusion \\
\hline Meng 2009 & $\begin{array}{l}\text { Combined treatments (conventional therapy, filgrastim, } \\
\text { MSCs, filgrastim + MSCs) }\end{array}$ \\
\hline Mohamed Ibrahim 2016 & Not RCT \\
\hline Moniche 2012 & Not RCT \\
\hline Napgal 2016 & Not RCT \\
\hline NCT01297413 & Not RCT \\
\hline NCT02397018 & Not RCT \\
\hline NCT02795052 & Not RCT \\
\hline NCT03296618 & Not RCT \\
\hline NCT03384433 & Not RCT \\
\hline PISCES 2016 & Not RCT \\
\hline PISCES II 2017 & Not RCT \\
\hline Prasad 2012 & Not RCT \\
\hline Qiao 2014 & Not RCT \\
\hline Savitz 2005 & Not RCT \\
\hline Savitz 2011 & Not RCT \\
\hline Sharma 2014 & Not RCT \\
\hline Sinden 2009 & Not RCT \\
\hline Steinberg 2014 & Not RCT \\
\hline Suarez-Monteagudo 2009 & Not RCT \\
\hline Taguchi 2015 & Not RCT \\
\hline Vahidy 2012 & Not RCT \\
\hline Wanamaker 2015 & Not RCT \\
\hline Wang 2007 & Not RCT \\
\hline Wang 2013 & Not RCT \\
\hline Yang 2005 & Not RCT \\
\hline Yang 2007 & Not RCT \\
\hline
\end{tabular}




\begin{tabular}{ll}
\hline Study & Reason for exclusion \\
\hline
\end{tabular}

$\mathrm{RCT}$ : randomized controlled trial

Characteristics of studies awaiting assessment [ordered by study ID]

\section{ChiCTR-INR-16008908}

\begin{tabular}{ll}
\hline Methods & Randomized parallel controlled trial \\
\hline Participants & 62 participants with NIHSS scores between 15 and 25,1 to 3 months after onset of ischemic stroke \\
\hline Interventions & Intrathecal injection of allogenic bone marrow-derived mesenchymal stem cells \\
\hline Outcomes & $\begin{array}{l}\text { Efficacy evaluated with mRS scale, NIHSS, infarct volume and mortality within } 13 \text { months after } \\
\text { treatment }\end{array}$ \\
\hline Notes & \\
\hline
\end{tabular}

\section{Kondziolka 2005}

\begin{tabular}{ll}
\hline Methods & RCT \\
\hline Participants & $\begin{array}{l}18 \text { participants with fixed motor deficits, } 1 \text { to } 6 \text { years following a basal ganglia ischemic or hemor- } \\
\text { rhagic stroke }\end{array}$ \\
\hline Interventions & $\begin{array}{l}\text { Stereotactic implantation of cultured neuronal cells produced from the NT2/D1 cell line derived } \\
\text { from a human teratocarcinoma }\end{array}$ \\
\hline Outcomes & $\begin{array}{l}\text { Efficacy evaluated with European Stroke Scale motor score, Fugl-Meyer, Action Research Arm Test, } \\
\text { Stroke Impact Scale scores and the results of other motor, neuropsychological and functional tests } \\
\text { at } 6 \text { months }\end{array}$ \\
\hline Notes & $\begin{array}{l}\text { Separated results for ischemic and hemorrhagic stroke participants were not available from the } \\
\text { publications }\end{array}$ \\
\hline
\end{tabular}

\section{NCT01310114}

\begin{tabular}{ll}
\hline Methods & Randomized controlled dose-escalation trial \\
\hline Participants & 44 participants with acute ischemic stroke \\
\hline Interventions & Intravenous infusion of human placenta-derived cells (PDA001) \\
\hline Outcomes & Safety and tolerability up to 2 years \\
\hline Notes & \\
\hline
\end{tabular}


NCT01468064

\begin{tabular}{ll}
\hline Methods & RCT \\
\hline Participants & 20 participants with acute cerebral infarct within the MCA territory and severe neurological deficit \\
\hline Interventions & $\begin{array}{l}\text { Intravenous infusion of autologous transplantation of ex vivo expanded bone marrow stromal cells } \\
\text { and endothelial progenitor cells }\end{array}$ \\
\hline Outcomes & Safety and efficacy up to 1 year \\
\hline Notes & \\
\hline
\end{tabular}

NCT01518231

\begin{tabular}{ll}
\hline Methods & RCT \\
\hline Participants & 40 participants with ischemic stroke in the internal carotid artery territory during the previous year \\
\hline Interventions & Intrarterial infusion of autologous Peripheral Hematopoietic Stem Cell \\
\hline Outcomes & Safety and efficacy up to 1 year \\
\hline Notes & \\
\hline
\end{tabular}

\section{NCT02378974}

\begin{tabular}{ll}
\hline Methods & Randomized controlled dose-escalation trial \\
\hline Participants & 18 participants within 7 days of onset of ischemic stroke \\
\hline Interventions & Intravenous infusion of Cordstem-ST \\
\hline Outcomes & Safety and efficacy up to 6 months \\
\hline Notes & \\
\hline
\end{tabular}

NCT02564328

\begin{tabular}{ll}
\hline Methods & RCT \\
\hline Participants & 40 participants with chronic ischemic stroke (between 6 and 60 months after stroke) \\
\hline Interventions & Intravenous infusion of autologous bone marrow mesenchymal stem cells \\
\hline Outcomes & Safety and efficacy up to 1 year \\
\hline Notes & \\
\hline
\end{tabular}


NCT02605707

\begin{tabular}{ll}
\hline Methods & RCT \\
\hline Participants & 30 participants with chronic ischemic stroke (between 6 and 60 months after stroke) \\
\hline Interventions & Intravenous infusion of autologous endothelial progenitor cells \\
\hline Outcomes & Safety and efficacy up to 1 year \\
\hline Notes & \\
\hline
\end{tabular}

NCT03176498

\begin{tabular}{ll}
\hline Methods & RCT \\
\hline Participants & 40 participants with ischemic stroke, in the convalescent period \\
\hline Interventions & Intravenous infusion of allogeneic umbilical cord mesenchymal stem cells \\
\hline Outcomes & Efficacy up to 6 months
\end{tabular}

\section{Notes}

\section{NCT03186456}

\begin{tabular}{ll}
\hline Methods & RCT \\
\hline Participants & 40 participants with acute ischemic stroke \\
\hline Interventions & Intravenous infusion of allogeneic umbilical cord mesenchymal stem cells \\
\hline Outcomes & Safety and efficacy up to 26 weeks \\
\hline Notes & \\
\hline
\end{tabular}

\section{Sych 2012}

\begin{tabular}{ll}
\hline Methods & RCT \\
\hline Participants & $\begin{array}{l}27 \text { participants with brain infarction, } 11 \text { in the treatment group and } 16 \text { in the control group, treated } \\
3 \text { months after onset of stroke }\end{array}$ \\
\hline Interventions & $\begin{array}{l}\text { Transplantation of hematopoietic and non-hematopoietic mesenchymal and ectodermal fetal } \\
\text { stem cells, harvested from germ layers of internal organs of } 4 \text { to } 8 \text { week-old fetuses }\end{array}$ \\
\hline Outcomes & $\begin{array}{l}\text { Evaluation of cognitive status (MMSE), frontal lobe dysfunction (FAB), and brain perfusion (tran- } \\
\text { scranial doppler) }\end{array}$
\end{tabular}

Notes 
Yavagal 2015

\begin{tabular}{ll}
\hline Methods & Randomized, sham-controlled clinical trial \\
\hline Participants & $\begin{array}{l}\text { Participants with anterior circulation ischemic stroke, treated between } 9 \text { and } 19 \text { days after onset of } \\
\text { stroke }\end{array}$ \\
\hline Interventions & Intracarotid infusion of autologous bone marrow cells (ALD-401) \\
\hline Outcomes & Safety, efficacy and reduction in stroke volume at 1 year \\
\hline Notes & \\
\hline
\end{tabular}

FAB: Frontal Assessment Battery

MCA: middle cerebral artery

MMSE: Mini Mental State Examination

mRS: modified Rankin Score

NIHSS: National Institutes of Health Stroke Scale

$\mathrm{RCT}$ : randomized controlled trial

Characteristics of ongoing studies [ordered by study ID]

Bhasin 2016

\begin{tabular}{ll}
\hline Trial name or title & Intravenous bone marrow-derived mononuclear stem cells in chronic ischemic stroke \\
\hline Methods & Randomized, controlled clinical trial \\
\hline Participants & 20 participants with chronic motor deficit from ischemic stroke \\
\hline Interventions & $\begin{array}{l}\text { Intravenous infusion of bone marrow derived mononuclear stem cells (mean } 60 \text { to } 70 \text { million) or } \\
\text { placebo }\end{array}$ \\
\hline Outcomes & $\begin{array}{l}\text { Efficacy evaluated with Fugl Meyer scale, modified BI, Medical Research Council Grade, Ashworth } \\
\text { Tone Scale }\end{array}$ \\
\hline Starting date & $\begin{array}{l}\text { 2014 } \\
\text { Contact information }\end{array}$ \\
\hline Prof MV Padma Srivastava, Department of Neurology, All India Institute of Medical Sciences, New \\
\hline Delhi, India
\end{tabular}

Detante 2013

\begin{tabular}{ll}
\hline Trial name or title & Intravenous Stem cells after Ischemic Stroke (ISIS) \\
\hline Methods & Randomized, controlled, open clinical trial \\
\hline Participants & 31 participants with subacute ischemic stroke \\
\hline Interventions & $\begin{array}{l}\text { Intravenous injection of low dose (100 million) or high dose (300 million) of autologous bone mar- } \\
\text { row mesenchymal stem cells; control group without intervention nor placebo }\end{array}$ \\
\hline
\end{tabular}


Detante 2013 (Continued)

Outcomes

Functional recovery and neuroradiological outcome by multimodal MRI (anatomic, activation, vasoreactivity, functional, and structural connectivity)

\begin{tabular}{ll}
\hline Starting date & 2010 \\
\hline Contact information & Dr Olivier Detante, University Hospital, Grenoble, France \\
\hline Notes & $\begin{array}{l}3 \text { participants did not receive the treatment because of karyotype abnormalities during cell cul- } \\
\text { ture; recruitment is complete, 2-year follow-up is ongoing }\end{array}$ \\
\hline
\end{tabular}

Diez-Tejedor 2014

\begin{tabular}{ll}
\hline Trial name or title & AMASCIS-01 \\
\hline Methods & Double-blind, randomized, controlled, phase Il clinical trial \\
\hline Participants & 19 participants with acute or subacute ischemic stroke, and NIHSS between 8 and 20 \\
\hline Interventions & $\begin{array}{l}\text { Intravenous administration of allogeneic mesenchymal stem cells from adipose tissue (1 million / } \\
\mathrm{kg} \text { ) within the first } 2 \text { weeks after the onset of stroke symptoms }\end{array}$ \\
\hline Outcomes & Safety and efficacy analysis (mRS, NIHSS, size of infarct, and biochemical markers) \\
\hline Starting date & 2014 \\
\hline Contact information & Dr Exuperio Diez-Tejedor, University Hospital La Paz, Madrid, Spain \\
\hline Notes &
\end{tabular}

\section{Honmou 2016}

\begin{tabular}{ll}
\hline Trial name or title & Phase III clinical trial using autologous mesenchymal stem cells for stroke patients \\
\hline Methods & Double-blind, randomized, controlled clinical trial \\
\hline Participants & Participants with subacute supratentorial cerebral infarction \\
\hline Interventions & $\begin{array}{l}\text { Intravenous infusion of auto-serum expanded bone marrow derived-autologous mesenchymal } \\
\text { stem cells within } 40 \text { days from onset }\end{array}$ \\
\hline Outcomes & Feasibility, safety, and efficacy of cell therapy \\
\hline Starting date & 2016 \\
\hline Contact information & Dr Osam Honmou, Research Institute for Frontier Medicine, Sapporo Medical University, Japan \\
\hline Notes &
\end{tabular}


Kim 2013

\begin{tabular}{ll}
\hline Trial name or title & STARTING-2 \\
\hline Methods & Single-blind, randomized, open clinical trial \\
\hline Participants & $\begin{array}{l}60 \text { participants with acute, subacute, or chronic ischemic stroke, and moderate to severe neurolog- } \\
\text { ic deficit }\end{array}$ \\
\hline Interventions & $\begin{array}{l}\text { Intravenous transplantation of autologous mesenchymal stem cells, expanded with autologous } \\
\text { serum }\end{array}$ \\
\hline Outcomes & Functional endpoints, based on categorical shift in mRS, and neurologic deficits \\
\hline Starting date & 2012 \\
\hline Contact information & $\begin{array}{l}\text { Dr Oh Young Bang, Samsung Medical Center, Sungkyunkwan University School of Medicine, Seoul, } \\
\text { South Korea }\end{array}$ \\
\hline Notes & \\
\hline
\end{tabular}

\section{Moniche 2015}

\begin{tabular}{ll}
\hline Trial name or title & IBIS Trial \\
\hline Methods & Single-blind, randomized, controlled, phase II, multicenter, open clinical trial \\
\hline Participants & $\begin{array}{l}76 \text { participants with acute ischemic stroke of moderate to severe intensity (NIHSS } 6 \text { to 20), involv- } \\
\text { ing the MCA }\end{array}$ \\
\hline Interventions & Intra-arterial infusion of 2 or 5 millions/kg mononuclear autologous bone marrow stem cells \\
\hline Outcomes & Functional outcomes evaluated with mRS and BI \\
\hline Starting date & 2015 \\
\hline Contact information & Dr Francisco Moniche, Hospitales Universitarios Virgen del Rocio, Seville, Spain \\
\hline Notes & \\
\hline
\end{tabular}

\section{NCT02448641}

\begin{tabular}{ll}
\hline Trial name or title & ACTISSIMA \\
\hline Methods & Double-blind, randomized, controlled (interventional, sham-surgery), phase IIB clinical trial \\
\hline Participants & $\begin{array}{l}156 \text { participants with chronic motor deficit from ischemic stroke in subcortical region of MCA or } \\
\text { lenticulostriate artery }\end{array}$ \\
\hline Interventions & Stereotactic intracranial injection of 2.5 or 5 million modified stem cells (SB623) or placebo \\
\hline Outcomes & $\begin{array}{l}\text { Proportion of participants whose Fugl-Meyer Motor scale improved by } \geq 10 \text { points at month } 6 \text { from } \\
\text { baseline }\end{array}$ \\
\hline
\end{tabular}


NCT02448641 (Continued)

\begin{tabular}{ll} 
Starting date & January 2016 \\
\hline Contact information & $\begin{array}{l}\text { Study Sponsor: SanBio, Inc } \\
\text { Principal Investigator: Gary Steinberg, Stanford Hospital and Clinics, School of Medicine }\end{array}$
\end{tabular}

\section{Notes}

\section{NCT02580019}

\begin{tabular}{|c|c|}
\hline Trial name or title & Umbilical cord derived mesenchymal stem cells treatment in ischemic stroke \\
\hline Methods & Randomized, controlled, phase Ila, open clinical trial \\
\hline Participants & Participants with subacute ischemic stroke and NIHSS $<24$ \\
\hline Interventions & $\begin{array}{l}\text { Intravenous injection of a single dose of } 2 \times 107 \text { human umbilical cord mesenchymal stem cells } \\
\text { once a week for } 4 \text { weeks }\end{array}$ \\
\hline Outcomes & Safety and efficacy assessed as comparison of NIHSS and mRS \\
\hline Starting date & 2016 \\
\hline Contact information & $\begin{array}{l}\text { Prof Duan Lian, Affiliated Hospital (307 Hospital), Academy of Military Medical Science, Beijing, Chi- } \\
\text { na }\end{array}$ \\
\hline Notes & \\
\hline
\end{tabular}

\section{NCT03004976}

\begin{tabular}{|c|c|}
\hline Trial name or title & Study of allogeneic umbilical cord blood infusion for adults with ischemic stroke (CoBIS 2) \\
\hline Methods & Double-blind, randomized, controlled, phase II, multicenter clinical trial \\
\hline Participants & 100 participants with acute ischemic stroke \\
\hline Interventions & A single intravenous infusion of umbilical cord blood or placebo \\
\hline Outcomes & Safety and efficacy analysis \\
\hline Starting date & 2017 \\
\hline Contact information & $\begin{array}{l}\text { Dr J Kurtzberg, Robertson Clinical and Translational Cell Therapy Program, Duke University, North } \\
\text { Carolina, US }\end{array}$ \\
\hline Notes & $\begin{array}{l}\text { Stem cells are supposed to be responsible, at least in part, for the mechanism of action of the um- } \\
\text { bilical cord blood }\end{array}$ \\
\hline
\end{tabular}

\section{NCT03545607}




\begin{tabular}{|c|c|}
\hline Methods & Double-blind, randomized, placebo-controlled, phase III, multicenter clinical trial \\
\hline Participants & 300 participants with acute ischemic stroke \\
\hline Interventions & $\begin{array}{l}\text { Intravenous infusion of } 1200 \text { million multipotent progenitor cells or placebo within } 18 \text { to } 36 \text { hours } \\
\text { from onset of stroke }\end{array}$ \\
\hline Outcomes & Efficacy endpoint, assessed with mRS, or combined mRS, BI, and NIHSS \\
\hline Starting date & 2018 \\
\hline Contact information & Athersys Clinical Trials Group \\
\hline Notes & \\
\hline
\end{tabular}

\begin{tabular}{ll}
\hline RESSTORE 2015 & RESSTORE \\
\hline Trial name or title & Randomized, controlled, phase Ilb, multicenter clinical trial \\
\hline Participants & 400 participants with ischemic stroke \\
\hline Interventions & Intravenous infusion of allogenic adipose tissue derived mesenchymal stem cells \\
\hline Outcomes & $\begin{array}{l}\text { Safety and efficacy (functional recovery) using clinical rating scales, multimodal MRI, and blood } \\
\text { biomarkers }\end{array}$ \\
\hline Starting date & 2015 \\
\hline Contact information & Dr Olivier Detante, University Hospital, Grenoble, France \\
\hline Notes & \\
\hline
\end{tabular}

\section{TREASURE 2018}

\begin{tabular}{ll}
\hline Trial name or title & TREASURE \\
\hline Methods & Double-blind, randomized, controlled, multicenter, phase II/III clinical trial \\
\hline Participants & 220 participants with acute ischemic stroke \\
\hline Interventions & $\begin{array}{l}\text { Intravenous infusion of } 1200 \text { million multipotent progenitor cells or placebo within } 18 \text { to } 36 \text { hours } \\
\text { of onset of stroke }\end{array}$ \\
\hline Outcomes & Safety and efficacy (the primary efficacy endpoint combines the mRS, BI, and NIHSS) \\
\hline Starting date & 2017 \\
\hline Contact information & Dr Kiyohiro Houkin, Hokkaido University Hospital, Sapporo, Japan \\
\hline
\end{tabular}

\section{Notes}


BI: Barthel Index

MCA: middle cerebral artery

MRI: magnetic resonance imaging

mRS: modified Rankin Score

NIHSS: National Institutes of Health Stroke Scale

\section{DATA AND ANALYSES}

\section{Comparison 1. Stem cell transplantation versus conventional treatments}

\begin{tabular}{|c|c|c|c|c|}
\hline Outcome or subgroup title & No. of studies & $\begin{array}{l}\text { No. of partici- } \\
\text { pants }\end{array}$ & Statistical method & Effect size \\
\hline $\begin{array}{l}1 \text { Neurologic impairment } \\
\text { (measured by NIHSS) }\end{array}$ & 5 & 319 & $\begin{array}{l}\text { Mean Difference (IV, Random, 95\% } \\
\mathrm{CI} \text { ) }\end{array}$ & $-1.49[-2.65,-0.33]$ \\
\hline $\begin{array}{l}2 \text { Neurologic impairment } \\
\text { (measured by NIHSS, by phase } \\
\text { of disease) }\end{array}$ & 5 & & $\begin{array}{l}\text { Mean Difference (IV, Random, 95\% } \\
\mathrm{CI})\end{array}$ & Subtotals only \\
\hline 2.1 Acute and subacute & 4 & 289 & $\begin{array}{l}\text { Mean Difference (IV, Random, 95\% } \\
\mathrm{CI})\end{array}$ & $-1.05[-2.03,-0.07]$ \\
\hline 2.2 Chronic & 1 & 30 & $\begin{array}{l}\text { Mean Difference (IV, Random, 95\% } \\
\mathrm{CI} \text { ) }\end{array}$ & $-3.20[-4.52,-1.88]$ \\
\hline $\begin{array}{l}3 \text { Neurologic impairment } \\
\text { (measured by NIHSS, by route } \\
\text { of administration) }\end{array}$ & 5 & & $\begin{array}{l}\text { Mean Difference (IV, Random, 95\% } \\
\mathrm{CI})\end{array}$ & Subtotals only \\
\hline 3.1 Intravenous & 2 & 249 & $\begin{array}{l}\text { Mean Difference (IV, Random, 95\% } \\
\mathrm{CI} \text { ) }\end{array}$ & $-0.47[-1.65,0.70]$ \\
\hline 3.2 Intracerebral & 1 & 30 & $\begin{array}{l}\text { Mean Difference (IV, Random, 95\% } \\
\mathrm{CI})\end{array}$ & $-3.20[-4.52,-1.88]$ \\
\hline $\begin{array}{l}\text { 3.3 Lumbar subarachnoid } \\
\text { space }\end{array}$ & 1 & 20 & $\begin{array}{l}\text { Mean Difference (IV, Random, 95\% } \\
\mathrm{CI} \text { ) }\end{array}$ & $-2.0[-3.19,-0.81]$ \\
\hline 3.4 Intra-arterial & 1 & 20 & $\begin{array}{l}\text { Mean Difference (IV, Random, 95\% } \\
\mathrm{CI} \text { ) }\end{array}$ & $-0.80[-3.07,1.47]$ \\
\hline $\begin{array}{l}4 \text { Disability (measured by } \\
\text { mRS) }\end{array}$ & 6 & 371 & $\begin{array}{l}\text { Mean Difference (IV, Random, 95\% } \\
\mathrm{CI})\end{array}$ & $-0.42[-0.86,0.02]$ \\
\hline $\begin{array}{l}5 \text { Disability (measured by mRS, } \\
\text { by phase of disease) }\end{array}$ & 6 & & $\begin{array}{l}\text { Mean Difference (IV, Random, 95\% } \\
\mathrm{CI})\end{array}$ & Subtotals only \\
\hline 5.1 Acute and subacute & 5 & 341 & $\begin{array}{l}\text { Mean Difference (IV, Random, 95\% } \\
\mathrm{CI})\end{array}$ & $-0.39[-0.97,0.19]$ \\
\hline 5.2 Chronic & 1 & 30 & $\begin{array}{l}\text { Mean Difference (IV, Random, 95\% } \\
\mathrm{CI} \text { ) }\end{array}$ & $-0.60[-0.90,-0.30]$ \\
\hline $\begin{array}{l}6 \text { Disability (measured by mRS, } \\
\text { by route of administration) }\end{array}$ & 6 & & $\begin{array}{l}\text { Mean Difference (IV, Random, 95\% } \\
\mathrm{Cl} \text { ) }\end{array}$ & Subtotals only \\
\hline
\end{tabular}




\begin{tabular}{|c|c|c|c|c|}
\hline Outcome or subgroup title & No. of studies & $\begin{array}{l}\text { No. of partici- } \\
\text { pants }\end{array}$ & Statistical method & Effect size \\
\hline 6.1 Intravenous & 3 & 301 & $\begin{array}{l}\text { Mean Difference (IV, Random, 95\% } \\
\mathrm{CI})\end{array}$ & $0.03[-0.28,0.34]$ \\
\hline 6.2 Intracerebral & 1 & 30 & $\begin{array}{l}\text { Mean Difference (IV, Random, 95\% } \\
\mathrm{CI})\end{array}$ & $-0.60[-0.90,-0.30]$ \\
\hline $\begin{array}{l}\text { 6.3 Lumbar subarachnoid } \\
\text { space }\end{array}$ & 1 & 20 & $\begin{array}{l}\text { Mean Difference (IV, Random, 95\% } \\
\mathrm{CI})\end{array}$ & $-1.10[-1.65,-0.55]$ \\
\hline 6.4 Intra-arterial & 1 & 20 & $\begin{array}{l}\text { Mean Difference (IV, Random, 95\% } \\
\mathrm{CI})\end{array}$ & $1.00[-2.76,0.76]$ \\
\hline $\begin{array}{l}7 \text { Dependency (measured by } \\
\mathrm{BI})\end{array}$ & 3 & 170 & $\begin{array}{l}\text { Mean Difference (IV, Random, 95\% } \\
\mathrm{CI})\end{array}$ & $14.09[-1.94,30.13]$ \\
\hline $\begin{array}{l}8 \text { Dependency (measured by } \\
\mathrm{Bl} \text {, by route of administration) }\end{array}$ & 3 & & $\begin{array}{l}\text { Mean Difference (IV, Random, 95\% } \\
\mathrm{CI})\end{array}$ & Subtotals only \\
\hline 8.1 Intravenous & 2 & 150 & $\begin{array}{l}\text { Mean Difference (IV, Random, 95\% } \\
\mathrm{Cl} \text { ) }\end{array}$ & $8.75[-9.84,27.35]$ \\
\hline $\begin{array}{l}8.2 \text { Lumbar subarachnoid } \\
\text { space }\end{array}$ & 1 & 20 & $\begin{array}{l}\text { Mean Difference (IV, Random, 95\% } \\
\mathrm{CI})\end{array}$ & $24.20[11.57,36.83]$ \\
\hline 9 Any cause of death & 6 & 371 & Risk Ratio (M-H, Random, 95\% Cl) & $0.66[0.39,1.14]$ \\
\hline $\begin{array}{l}10 \text { Severe worsening of neuro- } \\
\text { logical deficit }\end{array}$ & 4 & 321 & Risk Ratio (M-H, Random, 95\% Cl) & $1.39[0.51,3.79]$ \\
\hline 11 Infections & 4 & 321 & Risk Ratio (M-H, Random, 95\% Cl) & $0.80[0.54,1.17]$ \\
\hline $\begin{array}{l}12 \text { Neoplastic transformation } \\
\text { of ischemic lesion at longer- } \\
\text { term follow-up }\end{array}$ & 2 & 72 & Risk Ratio (M-H, Random, 95\% Cl) & $1.13[0.11,11.53]$ \\
\hline
\end{tabular}
Analysis 1.1. Comparison 1 Stem cell transplantation versus conventional
treatments, Outcome 1 Neurologic impairment (measured by NIHSS).

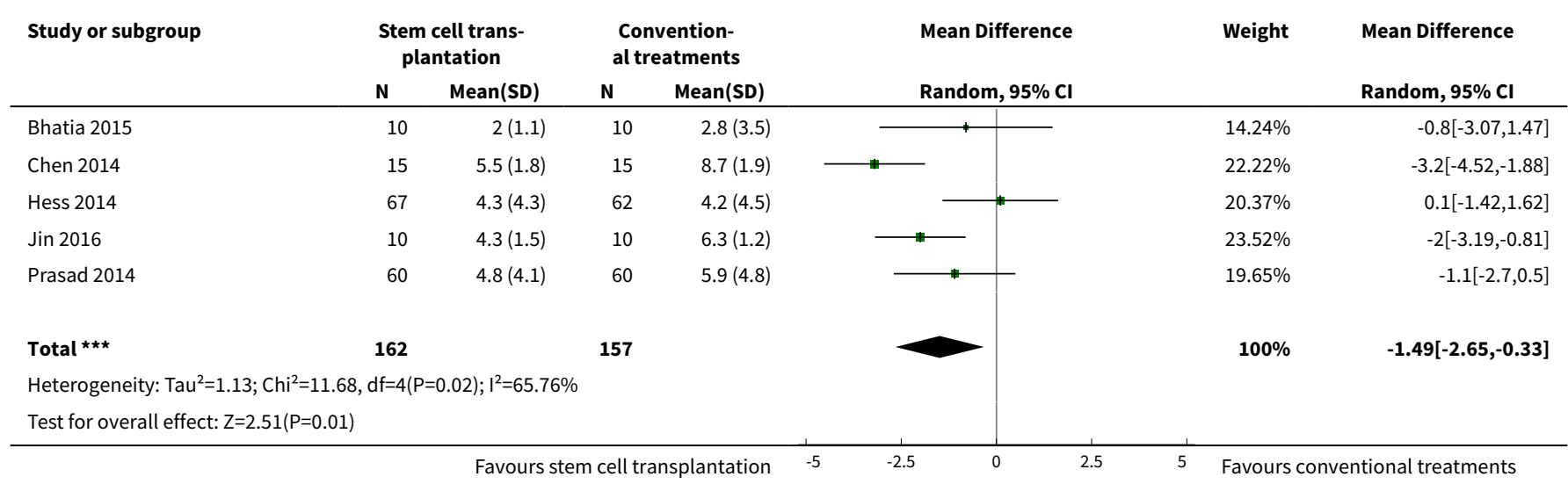


Analysis 1.2. Comparison 1 Stem cell transplantation versus conventional treatments, Outcome 2 Neurologic impairment (measured by NIHSS, by phase of disease).

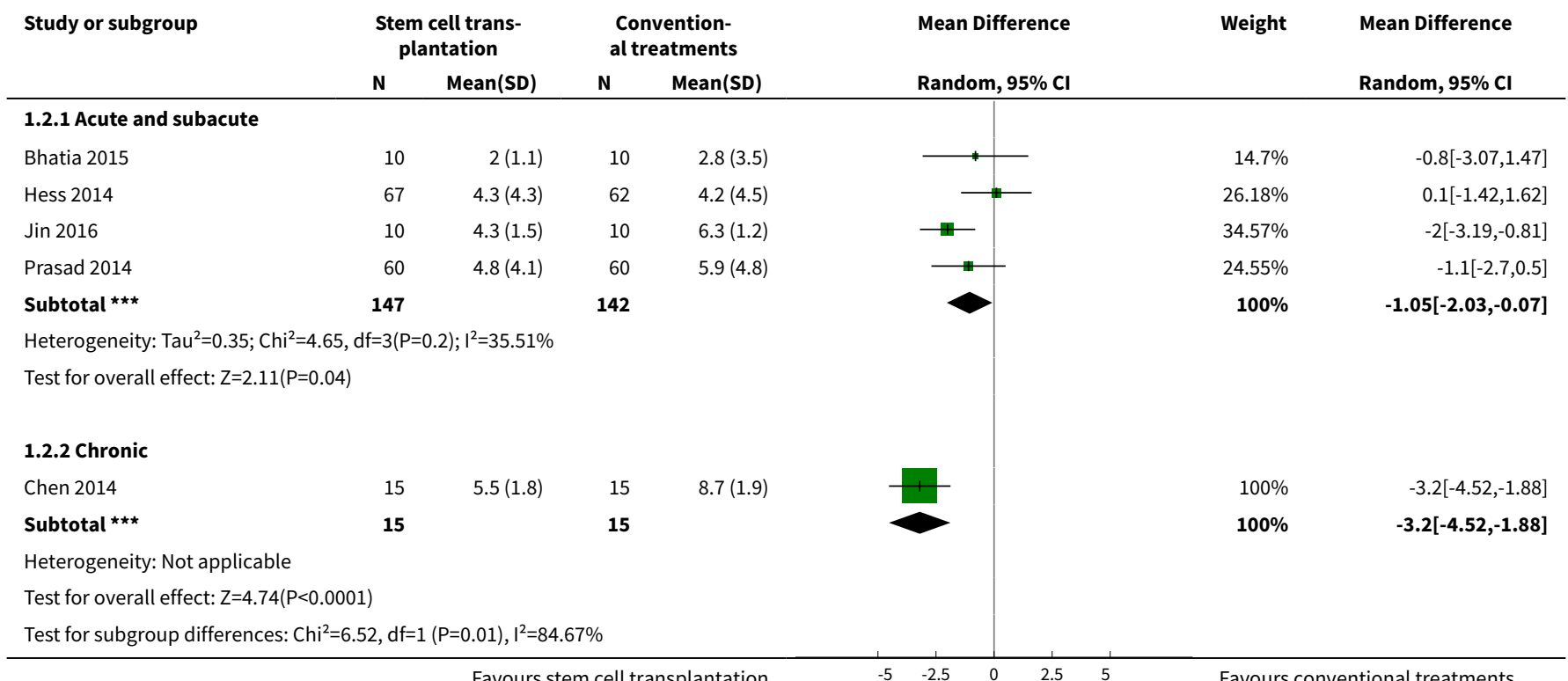

Analysis 1.3. Comparison 1 Stem cell transplantation versus conventional treatments, Outcome 3 Neurologic impairment (measured by NIHSS, by route of administration).

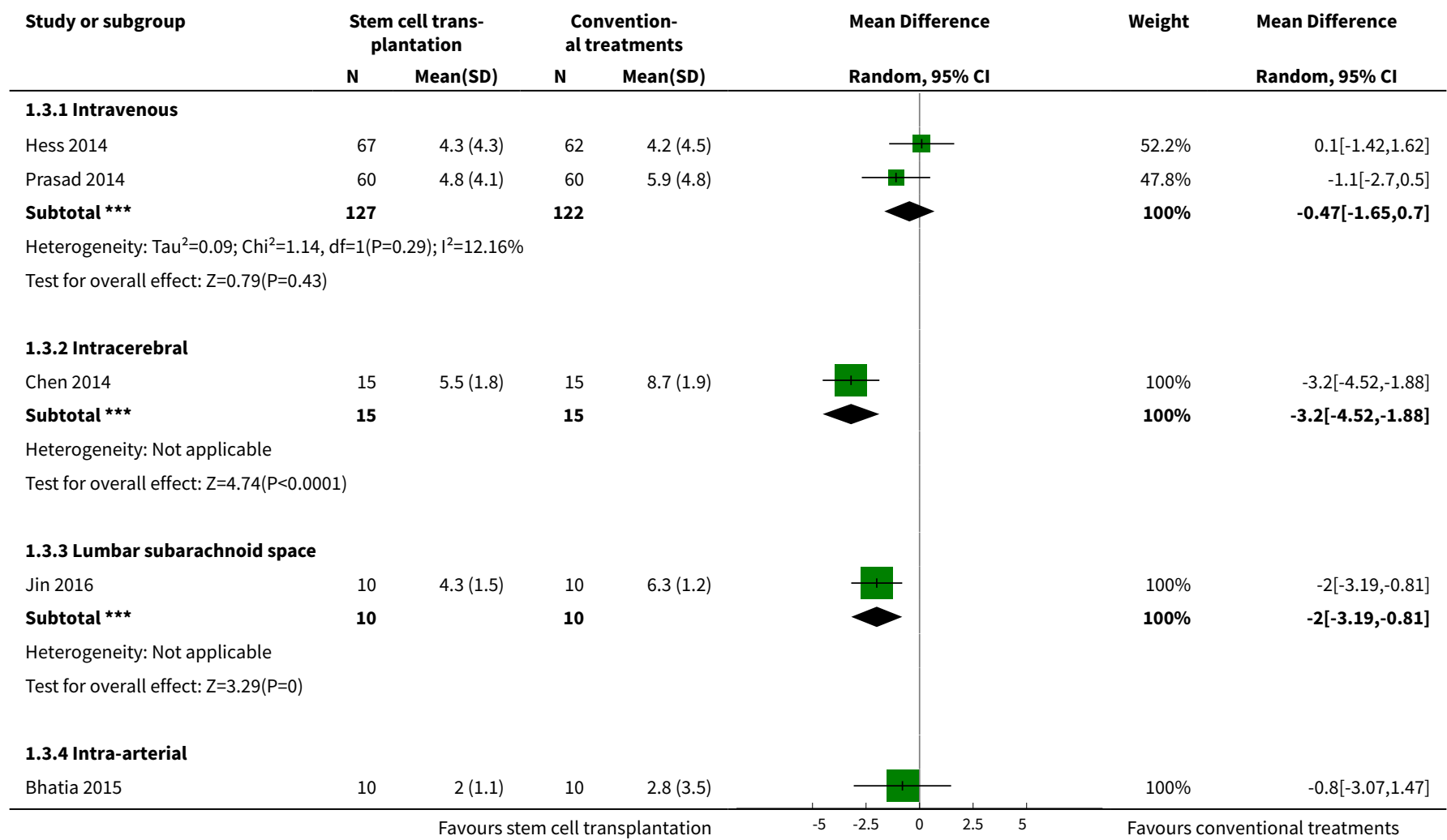




\begin{tabular}{|c|c|c|c|c|c|c|c|}
\hline \multirow[t]{2}{*}{ Study or subgroup } & \multicolumn{2}{|c|}{$\begin{array}{l}\text { Stem cell trans- } \\
\text { plantation }\end{array}$} & \multicolumn{2}{|c|}{$\begin{array}{l}\text { Convention- } \\
\text { al treatments }\end{array}$} & \multirow{2}{*}{$\begin{array}{l}\text { Mean Difference } \\
\text { Random, } 95 \% \mathrm{Cl}\end{array}$} & \multirow[t]{2}{*}{ Weight } & \multirow{2}{*}{$\begin{array}{l}\text { Mean Difference } \\
\text { Random, } 95 \% \mathrm{Cl}\end{array}$} \\
\hline & $\mathbf{N}$ & $\operatorname{Mean}(\mathrm{SD})$ & $\mathbf{N}$ & Mean(SD) & & & \\
\hline Subtotal $\star \star \star$ & 10 & & 10 & & & $100 \%$ & $-0.8[-3.07,1.47]$ \\
\hline \multicolumn{8}{|c|}{ Heterogeneity: Not applicable } \\
\hline \multicolumn{8}{|c|}{ Test for overall effect: $Z=0.69(P=0.49)$} \\
\hline \multicolumn{8}{|c|}{ Test for subgroup differences: $\mathrm{Chi}^{2}=9.96, \mathrm{df}=1(\mathrm{P}=0.02), \mathrm{I}^{2}=69.88 \%$} \\
\hline
\end{tabular}

Analysis 1.4. Comparison 1 Stem cell transplantation versus conventional treatments, Outcome 4 Disability (measured by mRS).

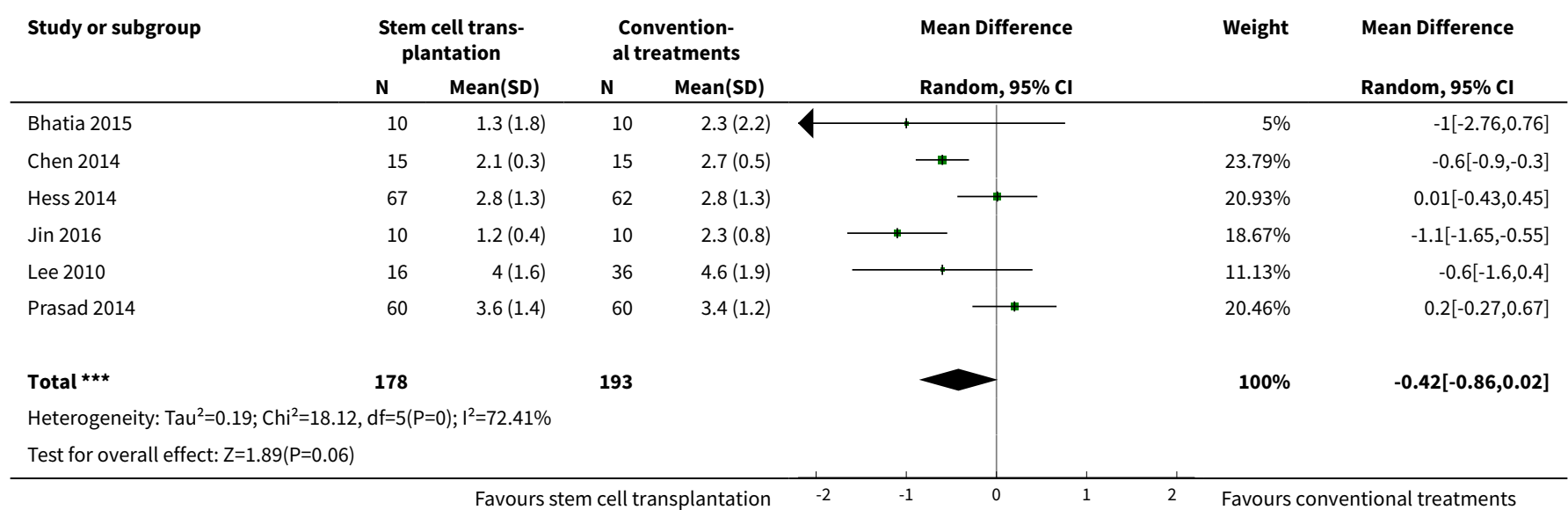

Analysis 1.5. Comparison 1 Stem cell transplantation versus conventional treatments, Outcome 5 Disability (measured by mRS, by phase of disease).

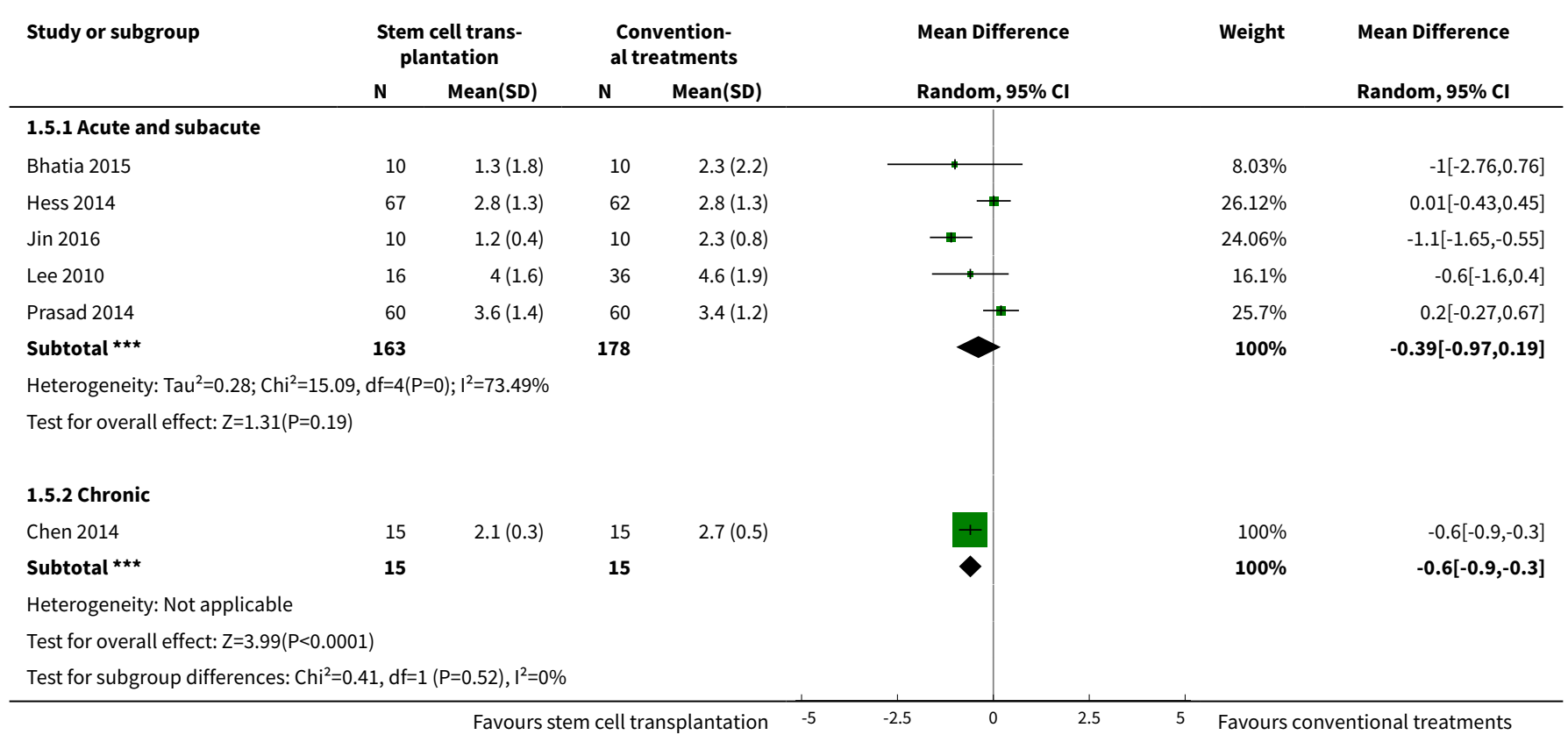


Analysis 1.6. Comparison 1 Stem cell transplantation versus conventional treatments, Outcome 6 Disability (measured by mRS, by route of administration).

\begin{tabular}{|c|c|c|c|c|c|c|c|}
\hline \multirow[t]{2}{*}{ Study or subgroup } & \multicolumn{2}{|c|}{$\begin{array}{l}\text { Stem cell trans- } \\
\text { plantation }\end{array}$} & \multicolumn{2}{|c|}{$\begin{array}{l}\text { Convention- } \\
\text { al treatments }\end{array}$} & \multirow{2}{*}{$\begin{array}{l}\text { Mean Difference } \\
\text { Random, } 95 \% \mathrm{Cl} \\
\end{array}$} & \multirow[t]{2}{*}{ Weight } & \multirow{2}{*}{$\begin{array}{l}\text { Mean Difference } \\
\text { Random, } 95 \% \mathrm{Cl}\end{array}$} \\
\hline & $\mathbf{N}$ & $\operatorname{Mean}(S D)$ & $\mathbf{N}$ & $\operatorname{Mean}(S D)$ & & & \\
\hline \multicolumn{8}{|l|}{ 1.6.1 Intravenous } \\
\hline Hess 2014 & 67 & $2.8(1.3)$ & 62 & $2.8(1.3)$ & & $47.42 \%$ & $0.01[-0.43,0.45]$ \\
\hline Lee 2010 & 16 & $4(1.6)$ & 36 & $4.6(1.9)$ & & $9.59 \%$ & $-0.6[-1.6,0.4]$ \\
\hline Prasad 2014 & 60 & $3.6(1.4)$ & 60 & $3.4(1.2)$ & - & $42.99 \%$ & $0.2[-0.27,0.67]$ \\
\hline 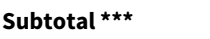 & 143 & & 158 & & & $100 \%$ & $0.03[-0.28,0.34]$ \\
\hline \multicolumn{8}{|c|}{ Heterogeneity: $\mathrm{Tau}^{2}=0 ; \mathrm{Chi}^{2}=2.04, \mathrm{df}=2(\mathrm{P}=0.36) ; \mathrm{I}^{2}=2.05 \%$} \\
\hline \multicolumn{8}{|c|}{ Test for overall effect: $Z=0.21(P=0.83)$} \\
\hline \multicolumn{8}{|l|}{ 1.6.2 Intracerebral } \\
\hline Chen 2014 & 15 & $2.1(0.3)$ & 15 & $2.7(0.5)$ & & $100 \%$ & $-0.6[-0.9,-0.3]$ \\
\hline Subtotal $\star \star \star ~$ & 15 & & 15 & & & $100 \%$ & $-0.6[-0.9,-0.3]$ \\
\hline \multicolumn{8}{|c|}{ Test for overall effect: $Z=3.99(P<0.0001)$} \\
\hline \multicolumn{8}{|c|}{ 1.6.3 Lumbar subarachnoid space } \\
\hline $\operatorname{Jin} 2016$ & 10 & $1.2(0.4)$ & 10 & $2.3(0.8)$ & & $100 \%$ & $-1.1[-1.65,-0.55]$ \\
\hline Subtotal $\star \star \star ~$ & 10 & & 10 & & & $100 \%$ & $-1.1[-1.65,-0.55]$ \\
\hline \multicolumn{8}{|c|}{ Heterogeneity: Not applicable } \\
\hline \multicolumn{8}{|c|}{ Test for overall effect: $Z=3.89(P=0)$} \\
\hline \multicolumn{8}{|l|}{ 1.6.4 Intra-arterial } \\
\hline Bhatia 2015 & 10 & $1.3(1.8)$ & 10 & $2.3(2.2)$ & - & $100 \%$ & $-1[-2.76,0.76]$ \\
\hline 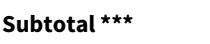 & 10 & & 10 & & & $100 \%$ & $-1[-2.76,0.76]$ \\
\hline \multicolumn{8}{|c|}{ Heterogeneity: Not applicable } \\
\hline \multicolumn{8}{|c|}{ Test for overall effect: $Z=1.11(P=0.27)$} \\
\hline
\end{tabular}

Analysis 1.7. Comparison 1 Stem cell transplantation versus conventional treatments, Outcome 7 Dependency (measured by BI).

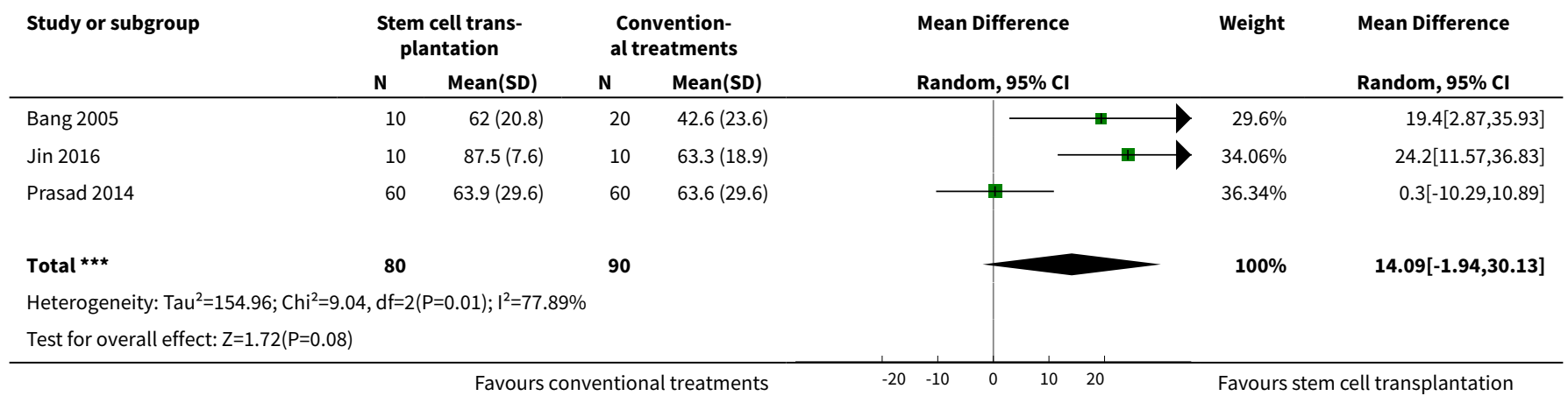


Analysis 1.8. Comparison 1 Stem cell transplantation versus conventional treatments, Outcome 8 Dependency (measured by BI, by route of administration).

\begin{tabular}{|c|c|c|c|c|c|c|c|}
\hline \multirow[t]{2}{*}{ Study or subgroup } & \multicolumn{2}{|c|}{$\begin{array}{l}\text { Stem cell trans- } \\
\text { plantation }\end{array}$} & \multicolumn{2}{|c|}{$\begin{array}{l}\text { Convention- } \\
\text { al treatments }\end{array}$} & \multirow{2}{*}{$\begin{array}{l}\text { Mean Difference } \\
\text { Random, } 95 \% \mathrm{Cl}\end{array}$} & \multirow[t]{2}{*}{ Weight } & \multirow{2}{*}{$\begin{array}{l}\text { Mean Difference } \\
\text { Random, } 95 \% \mathrm{Cl}\end{array}$} \\
\hline & $\mathbf{N}$ & Mean(SD) & $\mathbf{N}$ & Mean(SD) & & & \\
\hline \multicolumn{8}{|l|}{ 1.8.1 Intravenous } \\
\hline Bang 2005 & 10 & $62(20.8)$ & 20 & $42.6(23.6)$ & 世 & $44.26 \%$ & $19.4[2.87,35.93]$ \\
\hline Prasad 2014 & 60 & $63.9(29.6)$ & 60 & $63.6(29.6)$ & & $55.74 \%$ & $0.3[-10.29,10.89]$ \\
\hline Subtotal $\star \star \star$ & 70 & & 80 & & & $100 \%$ & $8.75[-9.84,27.35]$ \\
\hline \multicolumn{8}{|c|}{ Heterogeneity: $\mathrm{Tau}^{2}=132.25 ; \mathrm{Chi}^{2}=3.64, \mathrm{df}=1(\mathrm{P}=0.06) ; \mathrm{I}^{2}=72.5 \%$} \\
\hline \multicolumn{8}{|c|}{ Test for overall effect: $Z=0.92(P=0.36)$} \\
\hline \multicolumn{8}{|c|}{ 1.8.2 Lumbar subarachnoid space } \\
\hline Jin 2016 & 10 & $87.5(7.6)$ & 10 & $63.3(18.9)$ & & $100 \%$ & $24.2[11.57,36.83]$ \\
\hline Subtotal $\star \star \star ~$ & 10 & & 10 & & & $100 \%$ & $24.2[11.57,36.83]$ \\
\hline \multicolumn{8}{|c|}{ Heterogeneity: Not applicable } \\
\hline \multicolumn{8}{|c|}{ Test for subgroup differences: $\mathrm{Chi}^{2}=1.81, \mathrm{df}=1(\mathrm{P}=0.18), \mathrm{I}^{2}=44.89 \%$} \\
\hline
\end{tabular}

Favours conventional treatments

\section{Analysis 1.9. Comparison 1 Stem cell transplantation versus conventional treatments, Outcome 9 Any cause of death.}

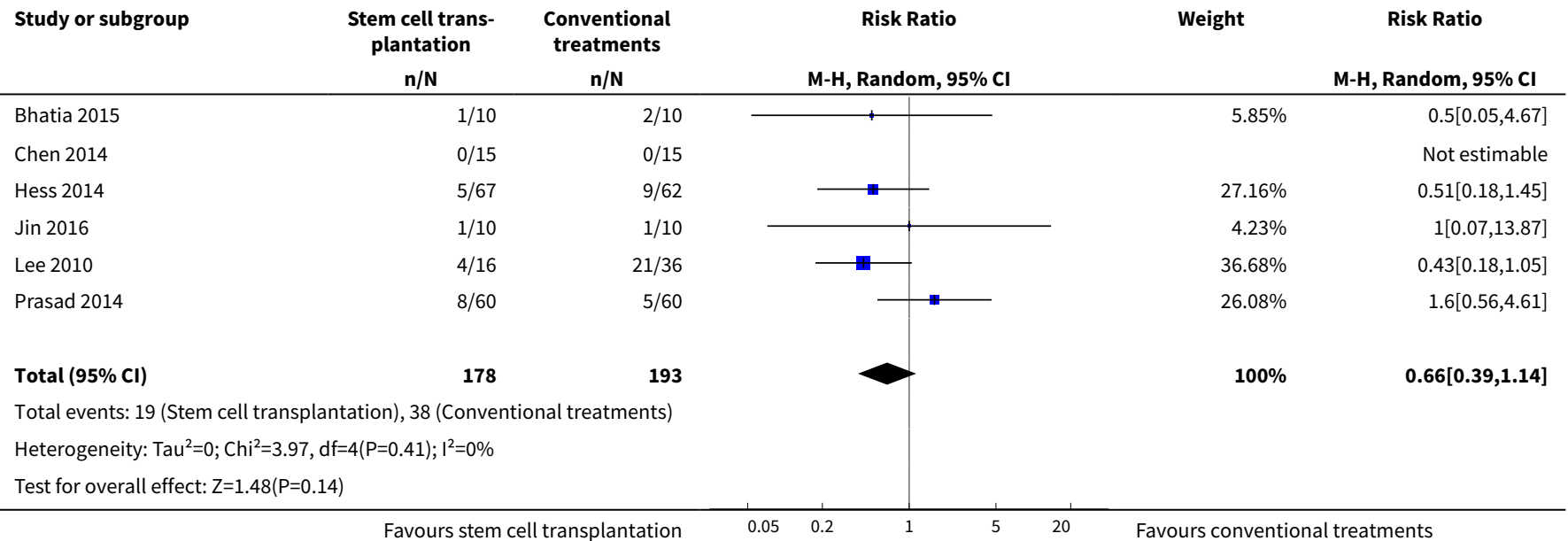

Analysis 1.10. Comparison 1 Stem cell transplantation versus conventional treatments, Outcome 10 Severe worsening of neurological deficit.

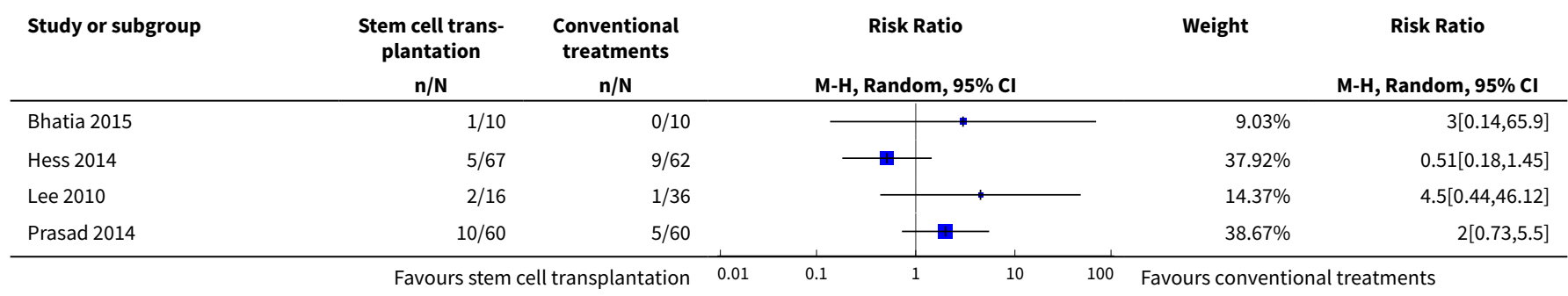




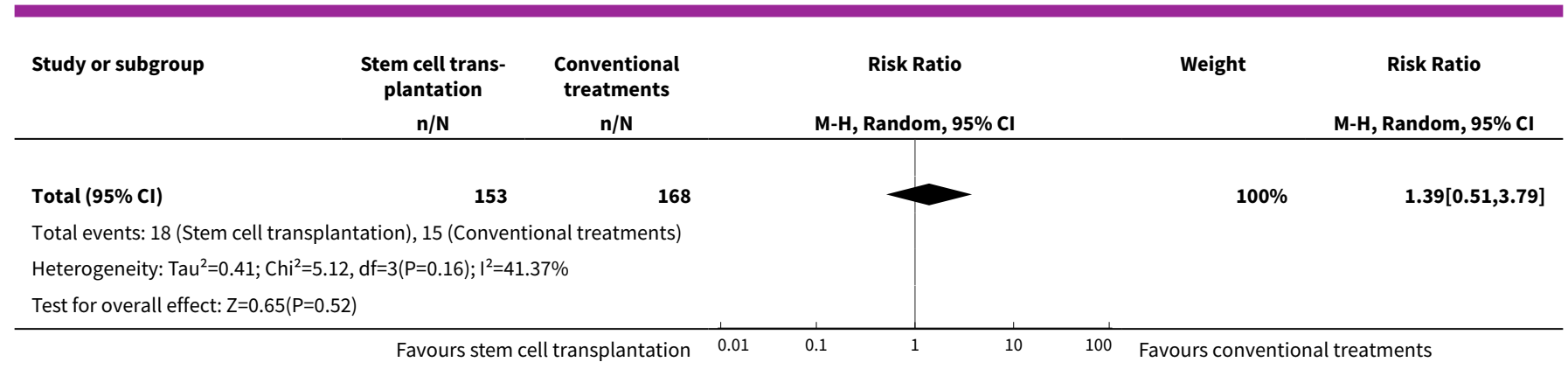

\section{Analysis 1.11. Comparison 1 Stem cell transplantation versus conventional treatments, Outcome 11 Infections.}

\begin{tabular}{|c|c|c|c|c|c|}
\hline Study or subgroup & $\begin{array}{c}\text { Stem cell trans- } \\
\text { plantation } \\
\mathbf{n} / \mathbf{N}\end{array}$ & $\begin{array}{c}\text { Conventional } \\
\text { treatments } \\
\mathbf{n} / \mathbf{N} \\
\end{array}$ & $\begin{array}{c}\text { Risk Ratio } \\
\text { M-H, Random, } 95 \% \mathrm{Cl}\end{array}$ & Weight & $\begin{array}{c}\text { Risk Ratio } \\
\text { M-H, Random, } 95 \% \mathrm{Cl}\end{array}$ \\
\hline Bhatia 2015 & $0 / 10$ & $0 / 10$ & & & Not estimable \\
\hline Hess 2014 & $25 / 67$ & $29 / 62$ & & $87.36 \%$ & $0.8[0.53,1.2]$ \\
\hline Lee 2010 & $3 / 16$ & $9 / 36$ & & $10.71 \%$ & $0.75[0.23,2.41]$ \\
\hline Prasad 2014 & $1 / 60$ & $1 / 60$ & & $1.93 \%$ & $1[0.06,15.62]$ \\
\hline Total $(95 \% \mathrm{Cl})$ & 153 & 168 & & $100 \%$ & $0.8[0.54,1.17]$ \\
\hline \multicolumn{6}{|c|}{ Total events: 29 (Stem cell transplantation), 39 (Conventional treatments) } \\
\hline \multicolumn{6}{|c|}{ Heterogeneity: $\mathrm{Tau}^{2}=0 ; \mathrm{Chi}^{2}=0.04, \mathrm{df}=2(\mathrm{P}=0.98) ; \mathrm{I}^{2}=0 \%$} \\
\hline Test for overall effect & & & & & \\
\hline
\end{tabular}

Analysis 1.12. Comparison 1 Stem cell transplantation versus conventional treatments, Outcome 12 Neoplastic transformation of ischemic lesion at longer-term follow-up.

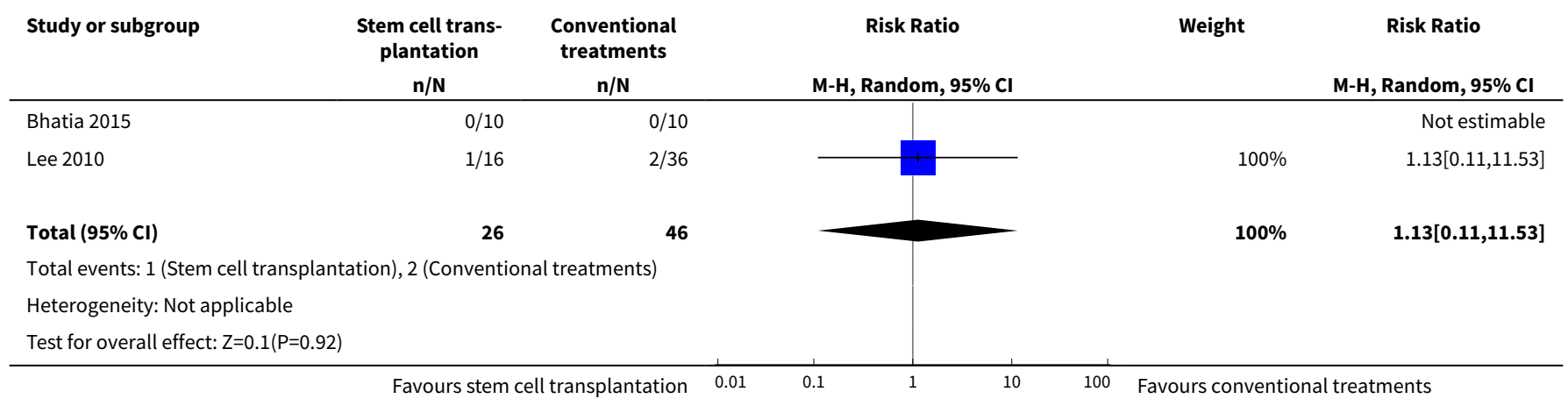

\section{AP PEN DICES}

\section{Appendix 1. CENTRAL search strategy}

We used the following search strategy for CENTRAL.

ID Search Hits 
\#1 [mh ^"cerebrovascular disease"] or [mh ^"cerebral artery disease"] or [mh ^"cerebrovascular accident"] or [mh ^stroke] or [mh $\wedge$ "vertebrobasilar insufficiency"] or [mh ^"carotid artery disease"] or [mh "carotid artery obstruction"] or [mh "brain infarction"] or [mh "brain ischemia"] or [mh "occlusive cerebrovascular disease"]

\#2 [mh^"stroke patient"] or [mh ^"stroke unit"]

\#3 (isch?emi* NEAR/6 (stroke* or apoplex* or cerebral vasc* or cerebrovasc* or cva or attack*)):ti,ab,kw (Word variations have been searched)

\#4 ((brain or cerebr ${ }^{\star}$ or cerebell* or vertebrobasil ${ }^{\star}$ or hemispher ${ }^{\star}$ or intracran* or intracerebral or infratentorial or supratentorial or middle cerebr ${ }^{\star}$ or mca $^{\star}$ or anterior circulation) NEAR/5 (isch?emi ${ }^{\star}$ or infarct ${ }^{\star}$ or thrombo ${ }^{\star}$ or emboli ${ }^{\star}$ or occlus ${ }^{\star}$ or hypoxi $\left.{ }^{\star}\right)$ ):ti,ab,kw $\left(\right.$ Word $^{\circ}$ variations have been searched)

\#5 \{or\#1-\#4\}

\#6 [mh ^"cell therapy"] or somatic cell therapy"] or [mh^"cell transplantation"] or [mh "stem cell transplantation"]

$\# 7$ [mh "stem cell"]

\#8 ((stem or progenitor or embryo* or fetal or foetal or umbilical or bone marrow or cord blood) NEAR/5 (cell or cells)):ti,ab,kw (Word variations have been searched)

\#9 (cell NEAR/5 (transplant* or graft*)):ti,ab,kw (Word variations have been searched)

\#10 (fibroblast* or myoblast*):ti,ab,kw (Word variations have been searched)

$\# 11$ [mh^"cell transplantation"]

$\# 12$ \{or \#6-\#11\}

$\# 13$ \#5 and \#12

\section{Appendix 2. MEDLINE search strategy}

We used the following search strategy for MEDLINE.

1. cerebrovascular disorders/ or basal ganglia cerebrovascular disease/ or exp brain ischemia/ or carotid artery diseases/ or carotid artery thrombosis/ or intracranial arterial diseases/ or cerebral arterial diseases/or exp "intracranial embolism and thrombosis"/ or exp stroke/ 2. (isch?emi\$ adj6 (stroke\$ or apoplex\$ or cerebral vasc\$ or cerebrovasc\$ or cva or attack\$)).tw.

3. ( (brain or cerebr\$ or cerebell\$ or vertebrobasil\$ or hemispher\$ or intracran\$ or intracerebral or infratentorial or supratentorial or middle cerebr\$ or mca\$ or anterior circulation) adj5 (isch?emi\$ or infarct\$ or thrombo or emboli\$ or occlus\$ or hypoxi\$)).tw.

4. 1 or 2 or 3

5. cell transplantation/ or stem cell transplantation/ or cord blood stem cell transplantation/ or hematopoietic stem cell transplantation/ or mesenchymal stem cell transplantation/ or peripheral blood stem cell transplantation/

6. stem cells/ or adult stem cells/ or embryonic stem cells/ or fetal stem cells/ or fibroblasts/ or hematopoietic stem cells/ or myeloid progenitor cells/ or erythroid progenitor cells/ or mesenchymal stem cells/ or multipotent stem cells/ or exp myoblasts/ or pluripotent stem cells/ or totipotent stem cells/ or tumor stem cells/

7. exp cells/tr

8. ((stem or progenitor or embryo\$ or fetal or foetal or umbilical or bone marrow or cord blood) adj5 (cell or cells)).tw.

9. (cell adj5 (transplant\$ or graft\$)).tw.

10. (fibroblast\$ or myoblast\$).tw.

11. cell transplantation.jn.

12. 5 or 6 or 7 or 8 or 9 or 10 or 11

13. Randomized Controlled Trials as Topic/

14. Random Allocation/

15. Controlled Clinical Trials as Topic/

16. control groups/

17. clinical trials as topic/ or clinical trials, phase i as topic/ or clinical trials, phase ii as topic/ or clinical trials, phase iii as topic/ or clinical trials, phase iv as topic/

18. double-blind method/

19. single-blind method/

20. Placebos/

21. placebo effect/

22. Drug Evaluation/

23. Research Design/

24. randomized controlled trial.pt.

25. controlled clinical trial.pt.

26. (clinical trial or clinical trial phase i or clinical trial phase ii or clinical trial phase iii or clinical trial phase iv).pt.

27. (random\$ or RCT or RCTs).tw.

28. (controlled adj5 (trial\$ or stud\$)).tw.

29. (clinical\$ adj5 trial\$).tw.

30. ((control or treatment or experiment\$ or intervention) adj5 (group\$ or subject\$ or patient\$)).tw.

31. (quasi-random $\$$ or quasi random $\$$ or pseudo-random $\$$ or pseud or random $\$$ ).tw.

32. ((singl\$ or doubl\$ or tripl\$ or trebl\$) adj5 (blind\$ or mask\$)).tw. 
33. placebo\$.tw.

34. controls.tw.

35. exp animals/ not humans.sh.

36.13 or 14 or 15 or 16 or 17 or 18 or 19 or 20 or 21 or 22 or 23 or 24 or 25 or 26 or 27 or 28 or 29 or 30 or 31 or 32 or 33 or 34

37. exp animals/ not humans.sh.

38. 4 and 12 and 36

39. 38 not 37

\section{Appendix 3. Embase search strategy}

We used the following search strategy for Embase.

1. cerebrovascular disease/ or cerebral artery disease/ or cerebrovascular accident/ or stroke/ or vertebrobasilar insufficiency/ or carotid artery disease/ or exp carotid artery obstruction/ or exp brain infarction/ or exp brain ischemia/ or exp occlusive cerebrovascular disease/

2. stroke patient/ or stroke unit/

3. (isch?emi\$ adj6 (stroke\$ or apoplex\$ or cerebral vasc\$ or cerebrovasc\$ or cva or attack\$)).tw.

4. ( (brain or cerebr $\$$ or cerebell\$ or vertebrobasil\$ or hemispher $\$$ or intracran $\$$ or intracerebral or infratentorial or supratentorial or middle cerebr\$ or mca\$ or anterior circulation) adj5 (isch?emi\$ or infarct\$ or thrombo $\$$ or emboli\$ or occlus\$ or hypoxi\$)).tw.

5. 1 or 2 or 3 or 4

6. cell therapy/ or somatic cell therapy/ or cell transplantation/ or exp stem cell transplantation/

7. exp stem cell/

8. ((stem or progenitor or embryo\$ or fetal or foetal or umbilical or bone marrow or cord blood) adj5 (cell or cells)).tw.

9. (cell adj5 (transplant\$ or graft\$)).tw.

10. (fibroblast\$ or myoblast\$).tw.

11. cell transplantation.jn.

12. 6 or 7 or 8 or 9 or 10 or 11

13. Randomized Controlled Trial/

14. Randomization/

15. Controlled Study/

16. control group/

17. clinical trial/ or phase 1 clinical trial/ or phase 2 clinical trial/ or phase 3 clinical trial/ or phase 4 clinical trial/ or controlled clinical trial/

18. Crossover Procedure/

19. Double Blind Procedure/

20. Single Blind Procedure/ or triple blind procedure/

21. latin square design/

22. Parallel Design/

23. Placebo/

24. Multicenter Study/

25. experimental design/ or experimental study/ or quasi experimental study/

26. experimental therapy/

27. drug comparison/ or drug dose comparison/

28. drug screening/

29. EVALUATION/ or "EVALUATION AND FOLLOW UP"/ or evaluation research/ or clinical evaluation/

30. METHODOLOGY/

31. "types of study"/

32. research subject/

33. Comparative Study/

34. "systematic review"/

35. Meta Analysis/

36. random\$.tw.

37. (controlled adj5 (trial\$ or stud\$)).tw.

38. (clinical\$ adj5 trial\$).tw.

39. ((control or treatment or experiment\$ or intervention) adj5 (group\$ or subject\$ or patient\$)).tw.

40. (surgical adj5 (group\$ or subject\$ or patient\$)).tw.

41. (quasi-random $\$$ or quasi random\$ or pseudo-random $\$$ or pseudo random\$).tw.

42. ((multicenter or multicentre or therapeutic) adj5 (trial\$ or stud\$)).tw.

43. ((control or experiment\$ or conservative) adj5 (treatment or therapy or procedure or manage $\$)$ ).tw.

44. ((singl\$ or doubl\$ or tripl\$ or trebl\$) adj5 (blind\$ or mask\$)).tw.

45. (coin adj5 (flip or flipped or toss\$)).tw.

46. latin square.tw.

47. versus.tw.

48. (cross-over or cross over or crossover).tw. 
49. placebo\$.tw.

50. sham.tw.

51. (assign\$ or alternate or allocat\$ or counterbalance\$ or multiple baseline).tw.

52. controls.tw.

53. (treatment\$ adj6 order).tw.

54. (meta-analy $\$$ or metaanaly or meta analy $\$$ or systematic review or systematic overview).tw.

55.13 or 14 or 15 or 16 or 17 or 18 or 19 or 20 or 21 or 22 or 23 or 24 or 25 or 26 or 27 or 28 or 29 or 30 or 31 or 32 or 33 or 34 or 35 or 36 or

37 or 38 or 39 or 40 or 41 or 42 or 43 or 44 or 45 or 46 or 47 or 48 or 49 or 50 or 51 or 52 or 53 or 54

56. (exp animal/ or animal.hw. or nonhuman/) not (exp human/ or human cell/ or (human or humans).ti.)

57.5 and 12 and 55

58.57 not 56

\section{Appendix 4. BIOSIS search strategy}

We used the following search strategy for BIOSIS.

You searched for: TOPIC: (stroke or cerebr ${ }^{\star}$ ) AND TOPIC: (stem cell* or cell transplant* ${ }^{\star}$ AND TOPIC: (trial ${ }^{\star}$ or random $^{\star}$ or placebo* $^{\star}$ or blind ${ }^{\star}$ ) Timespan: All years.

Indexes: $\mathrm{BCl}$.

\section{WHAT'S NEW}

\begin{tabular}{lll}
\hline Date & Event & Description \\
\hline 23 February 2019 & $\begin{array}{l}\text { New citation required but conclusions } \\
\text { have not changed }\end{array}$ & Conclusions not changed \\
\hline 13 August 2018 & New search has been performed & $\begin{array}{l}\text { Search strategy updated. Six new trials with 371 participants } \\
\text { with ischemic stroke added. Meta-analysis of data from RCTs } \\
\text { completed when at least two studies were available for each out- } \\
\text { come. }\end{array}$ \\
\hline
\end{tabular}

\section{CONTRIBUTIONS OF AUTHORS}

Giorgio B Boncoraglio drafted the protocol, guided trial selection and assessment, contacted trialists about unpublished data, guided extraction of trial and outcome data, and drafted and approved the final manuscript of the review.

Michela Ranieri screened titles and abstracts of references identified by the search, searched electronic databases and conference proceedings, selected and assessed trials, extracted trial and outcome data, and contributed to and approved the final manuscript of the review.

Anna Bersano contributed to the conception and design of the protocol, screened titles and abstracts of references identified by the search, searched electronic databases and conference proceedings, selected and assessed trials, extracted trial and outcome data, and contributed to and approved the final manuscript of the review.

Eugenio A Parati contributed to the conception and design of the protocol, contributed to the search of unpublished data and interpretation of the data, and contributed to and approved the final manuscript of the review.

Cinzia Del Giovane analyzed the extracted data, and contributed to and approved the final manuscript of the review.

\section{DECLARATIONSOF INTEREST}

Giorgio Battista Boncoraglio: none known.

Michela Ranieri: none known.

Anna Bersano: none known.

Eugenio A Parati: none known.

Cinzia Del Giovane: none known.

\section{DIFFERENCES BETWEEN PROTOCOLANDREVIEW}

None 
INDEX TERMS

\section{Medical Subject Headings (MeSH)}

*Stem Cell Transplantation [methods]; Brain Ischemia ["therapy]; Randomized Controlled Trials as Topic; Stroke

\section{MeSH check words}

Humans 